
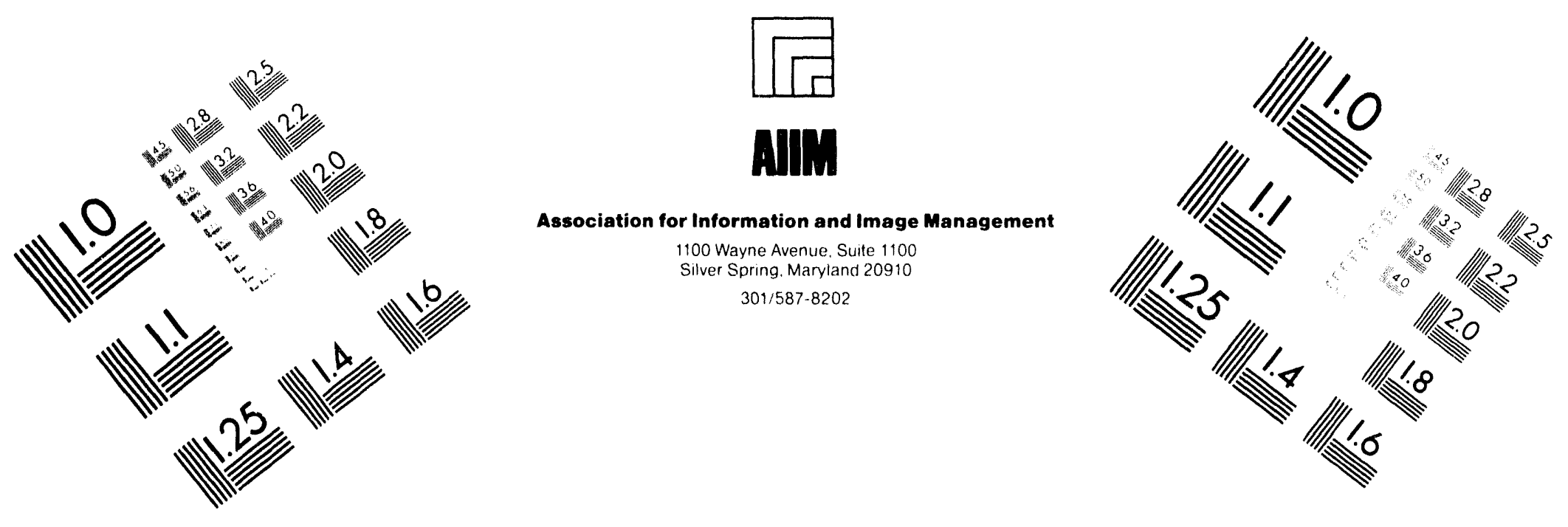

Centimeter

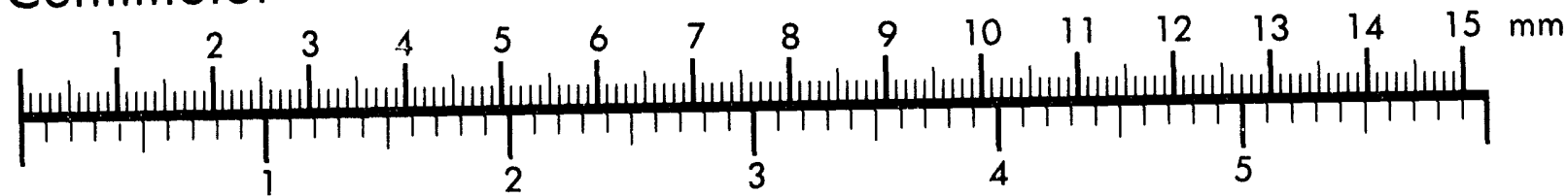
Inches
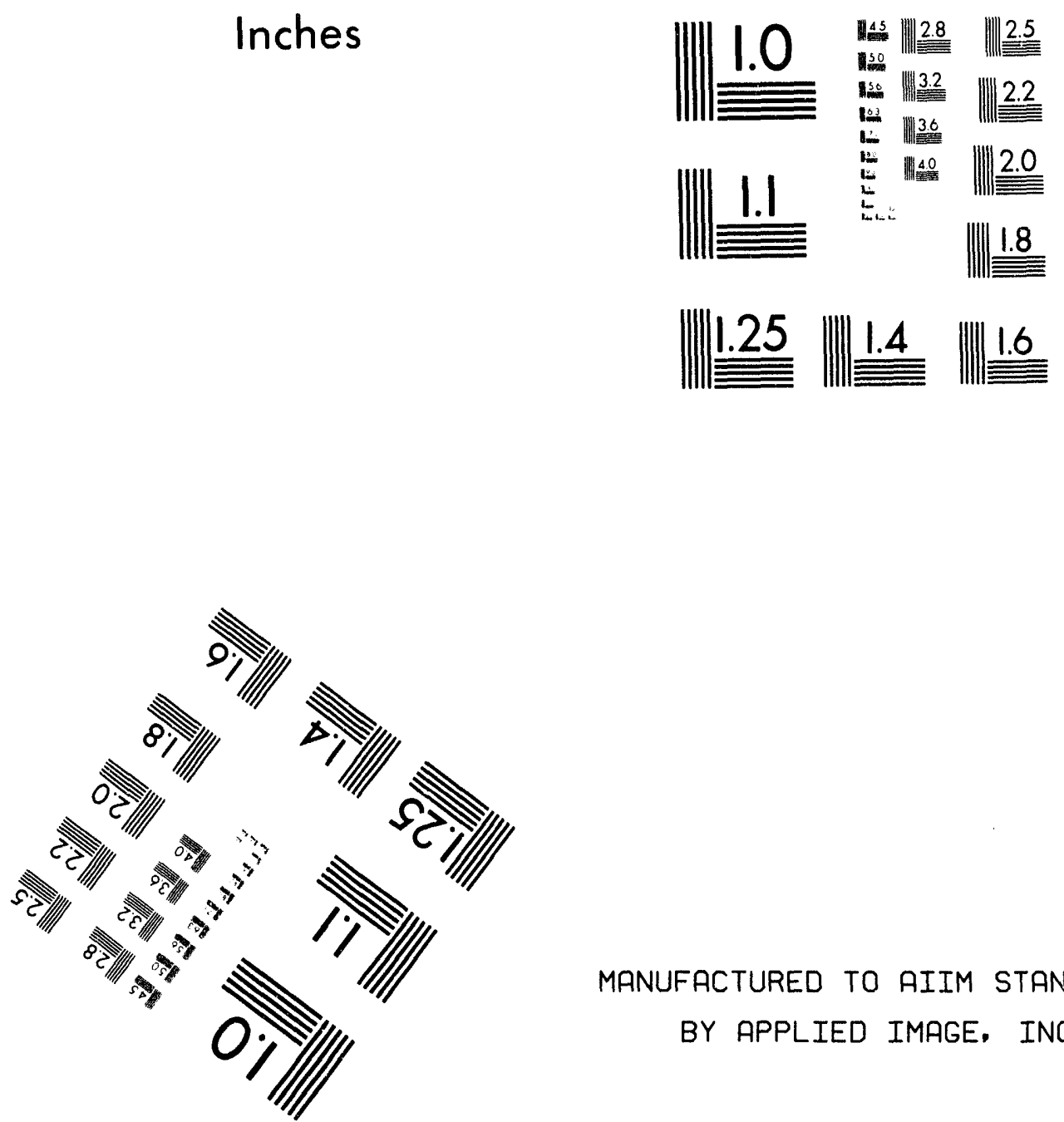

MANUFACTURED TO AIIM STANDARDS

BY APPLIED IMAGE, INC.

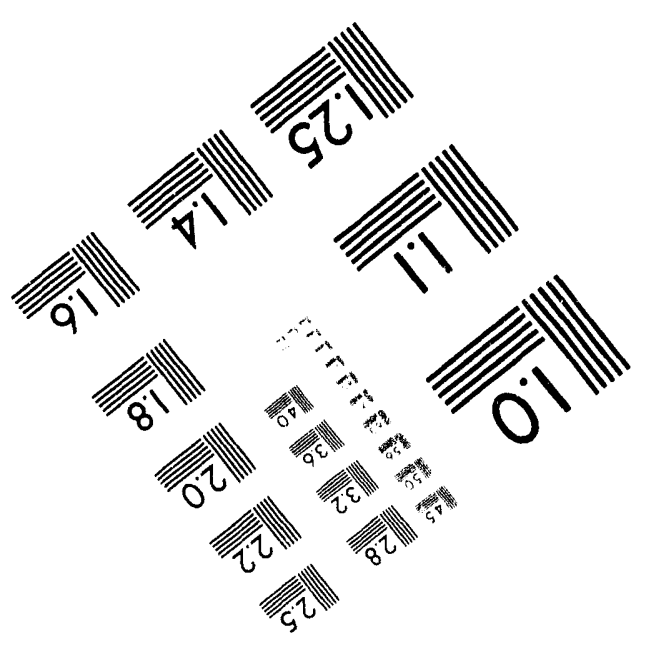



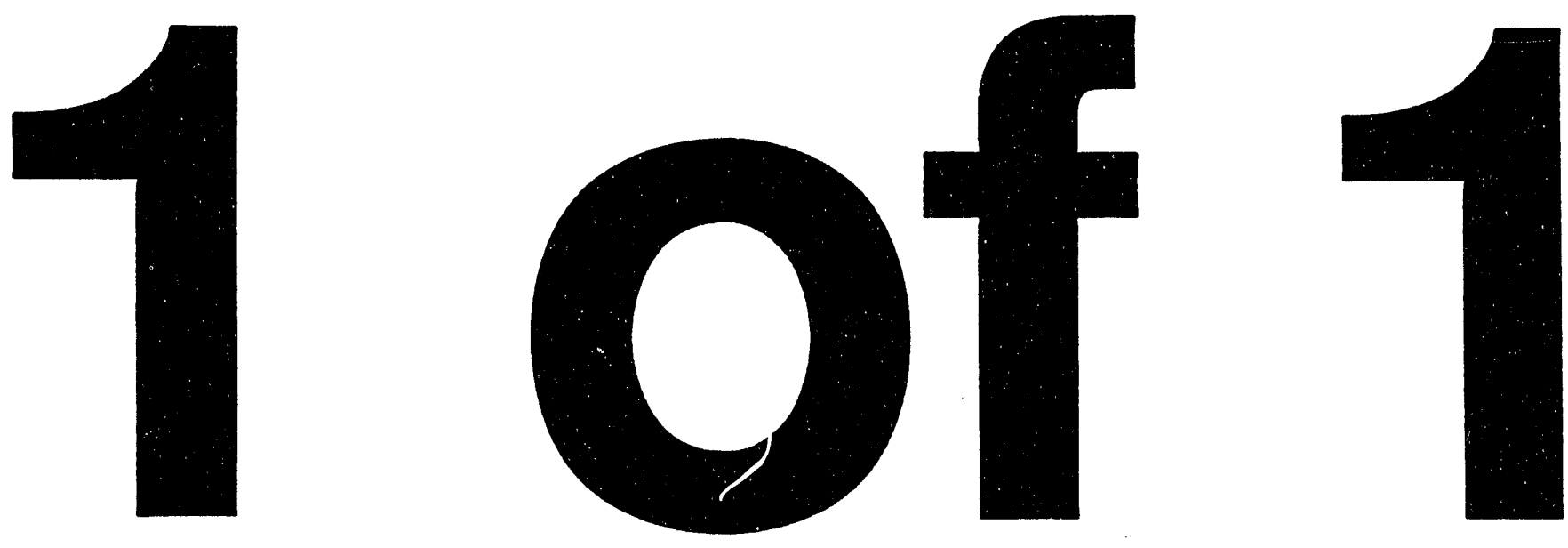
ENGINEERING DATA TRANSMITTAL

2. To: (Receiving Organization)

Distribution

5. Proj/Prog/Dept/Div: $\sqrt{ } 812 \mathrm{~A}$

8. Originator Remarks:

Supporting Document approval requested
3. From: (Originatıng Organization)

Water Resources Engineering \& Modelling
6. Cog/Prus Engr: MG Piepho

1. EDT 123311

4. Related EDT No

NIA

7. Purchase Order No:

NIA

9. Equip/Component No:

NIA

10. System/Bldg'Facility:

N/A

12. Major Assm Dwg No:

11. Receiver Remarks

N/A
13. Permit/Permit Application No

$N / A$

14. Required Response Date

9.94

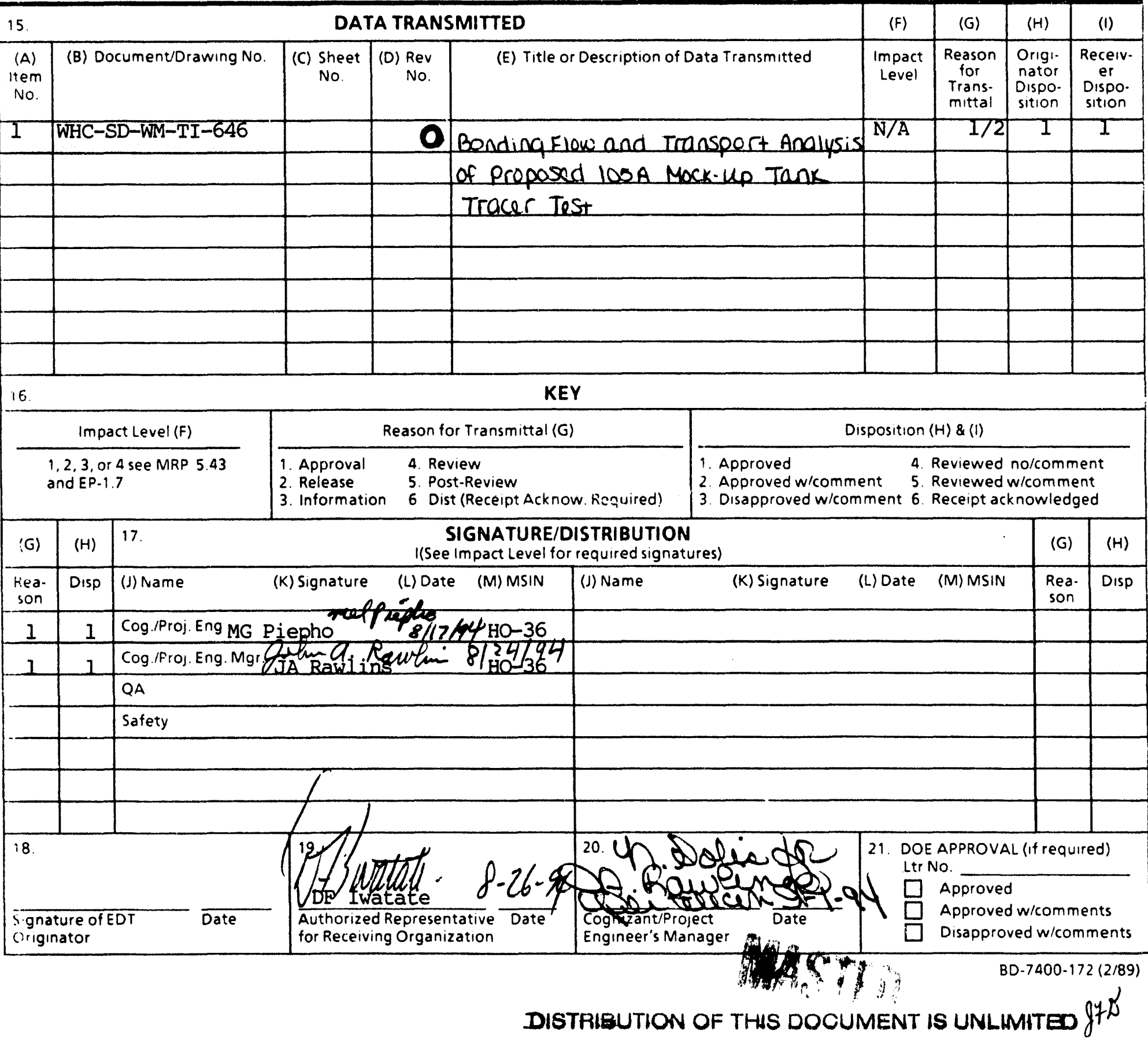




\section{RELEASE AUTHORIZATION}

Document Number: WHC-SD-WM-TI-646, REV. 0

Bonding Flow and Transportation Analys is of Proposed Document Title: $\quad$ 105A Mock-up Tank Tracer Test

Release Date: $\quad 9 / 1 / 94$

This document was reviewed following the procedures described in WHC-CM-3-4 and is:

APPROVED FOR PUBLIC RELEASE

***************

WHC Information Release Administration Specialist:

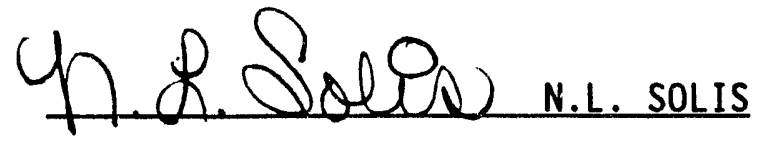

(Signature)

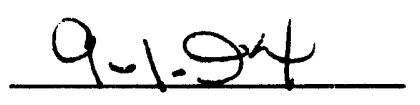

(Date) 


\begin{tabular}{|c|c|c|}
\hline $\begin{array}{l}\text { 2. Title } \\
\text { Bounding Flow and Transport Analys is of Proposed } \\
105 \text { A Mock-up Tank Tracer Test }\end{array}$ & $\begin{array}{l}\text { 3. Number } \\
\text { WHC-SD-WM-TI-646 }\end{array}$ & $\begin{array}{c}\text { 4. Rev No. } \\
0\end{array}$ \\
\hline $\begin{array}{l}\text { 5. Key words } \\
\text { Tracer Test } \\
\text { Salt Plume } \\
\text { Salt Concentration } \\
\text { Groundwater/vadose zone } \\
\text { Electrical Resistance } \\
\text { Tomography }\end{array}$ & $\begin{array}{l}\text { 6. Author } \\
\text { Name: M. G. Pieph } \\
\text { signature } \\
86910 / \mathrm{J} 812 \mathrm{~A} \\
\text { Organization/Charge coo }\end{array}$ & L \\
\hline
\end{tabular}

7. Abstract

Simulations were performed to estimate salt concentrations from a tracer-test injection at the 105A Mock-up Tank in the Semi-Works Area at Hanford. The estimated salt concentrations in the aquifer were compared to secondary drinking-water standards. The estimated salt concentrations are well below the maximum concentration level permitted.

8. PLOPPOSE AND USE OF DOCUMENT - This documnt was prepared for se with in the U.S. Department of E. $\mathrm{gy}$ and it contractors. It $s$ to be $D$ ed only to perform direct, or inegrate wor under U.S. DE artment of Energy nitracts. This documbt is ng approved for publ release unt il cviewed.

PATENT STATC - Th document copy, since it is dinsmitted in advance of pat ot cearance, is made available in onfiduce solely for use in rformance of work under itracts 1 th the U.S. Departm it onenergy. This document is $r$ to be published nor its conten otherm disseminated or used. or purposes other han specifi above befor patent approval fo such release or use 1 s been -cured, upen requ $t$, from the Pa int Counsel, U.S. Department of nergy Field Office, Richlard, wat

$\checkmark$ DISCLAIMER - This report was prepared as an account of work sponsored by an agency of the United States Government. Neither the United States Government nor any agency thereof, nor any of their employees, nor any of their contractors, subcontractors or their employees, makes any warranty, express or implied, or assumes any legal liability or responsibility for the accuracy, completeness, or any third party's use or the results of such use of any information, apparatus, product, or process disclosed, or represents that its use would not infringe privately owned rights. Reference herein to any specific commercial product, process, or service by trade name, trademark, manufacturer, or otherwise, does not necessarily constitute or imply $i$ ts endorsement, recommendation, or favoring by the United States Government or any agency thereof or its contractors or subcontractors. The views and opinions of authors expressed herein do not necessarily state or reflect those of the United States Government or any agency thereof.

9. Impact Level $N / A$
10.

RELEASE STAMP

OFFICIAL RELEASE

BY WNHC.

DATE SEP 021994

35 station 21 
WHC-SD-WM-TI-646, Rev. 0

\title{
BOUNDING FLOW AND TRANSPORT ANALYSIS \\ OF PROPOSED 105A MOCK-UP TANK TRACER TEST
}

\author{
Prepared for \\ WESTINGHOUSE HANFORD COMPANY
}

by

M. G. Piepho

Westinghouse Hanford Company

Richland, Washington

August 1994 
WHC-SD-WM-TI-646, Rev. 0

\section{EXECUTIVE SUMMARY}

The tracer test at the 105A mock-up tank near the inactive Semi-Works Plant in the 200 East Area was simulated with the PORFLOW code. The purpose of the simulation was to estimate the maximum tracer (salt) concentration in the underlying aquifer and compare it to the maximum contaminant level (MCL).

The MCL, as a secondary standard (a standard based on criteria other than health issues), for chlorine in drinking water is $250 \mathrm{ppm}$ or $250 \mathrm{mg} / \mathrm{L}$ (WAC 173-200). The chlorine MCL of $250 \mathrm{ppm}$ is equivalent to a salt (sodium chloride) MCL of approximately $415 \mathrm{ppm}$ or $415 \mathrm{mg} / \mathrm{L}$. The salt concentration in the proposed injection water of 2000 gallons ( 7570 liters) is $7000 \mathrm{mg} / \mathrm{L}$. Another injection of 2000 gallons of salt water may shortly follow the first injection. Most (six) of the simulations were for one injection, but one case included two injections.

The simulated results with one source injection, but with different tank and source locations, showed that the maximum concentration of salt in the vadose zone (unsaturated zone) reduces from $7000 \mathrm{mg} / \mathrm{L}$ to $10 \mathrm{mg} / \mathrm{L}$ in about 300 years after injection for most of the cases. It would be even lower in the aquifer, where the secondary standard applies, at later times. For the highrecharge $(5 \mathrm{~cm} / \mathrm{yr})$ case, the maximum salt concentration also reduces to 10 $\mathrm{mg} / \mathrm{L}$, but the time of the maximum, around 100 years after the injection, is much sooner than the lower recharge $(1 \mathrm{~cm} / \mathrm{yr})$ cases. This is because the higher recharge causes higher water velocities which results in smaller travel times for the salt plume. The largest maximum salt concentration in the vadose zone is realized for the case that excluded dispersion effects. Excluding dispersion effects is conservative since dispersion is known to exist and known to spread out the plume, resulting in lower concentrations. Even in this conservative no-dispersion case, the resulting maximum salt concentration of $40 \mathrm{mg} / \mathrm{L}$ in the aquifer at 800 years is less than the MCL (415 $\mathrm{mg} / \mathrm{L}$ ) for salt in drinking water.

One case was run which was the identical to the conservative nodispersion case except that a second injection of 7570 liters (total of 4000 gallons) was included in the simulation. For this conservative two-injection case, the maximum salt concentration is about $90 \mathrm{mg} / \mathrm{L}$ in the top part of the aquifer 800 years after the injections.

The possible effect of the salt plume on any existing radionuclides in nearby soils was not included in this analysis. However, since the inventory of radionuclides in nearby soils is expected to be very small and the water travel time of the injection source $(s)$ is greater than 300 years, short-lived radionuclides such as ${ }^{106} \mathrm{Ru},{ }^{90} \mathrm{Sr}$, and ${ }^{137} \mathrm{Cs}$, would decay away before reaching the aquifer. Furthermore, the large amount of water (more than one billion liters) that was discharged into the 216-C-9 pond would have transported most of the radionuclides to the aquifer already. In any case, the salt-water injections are expected to have negligible effects on the small amounts of any radionuclides that may be present near the 105A mock-up tank.

In summary, the tracer test with 4000 gallons (perhaps up to 16,000 gallons) is not expected to ever produce salt concentrations above its $\mathrm{MCL}$ in the aquifer and is expected to have negligible impact on the small amounts of residual radionuclides in nearby soils. More simulations will be made after the test when more knowledge is available. The test could be used to confirm the Hanford model methodology/capabilities of plumes in the vadose zone. 
WHC-SD-WM-TI-646, Rev. 0

TABLE OF CONTENTS

1.0 INTRODUCTION . . . . . . . . . . . . . . . . . . . 1

2.0 CONCEPTUAL MODEL . . . . . . . . . . . . . . . 2

3.0 MATHEMATICAL/NUMERICAL MODEL _ . . . . . . . . . . . 4

3.1 HYDRAULIC (FLOW) AND TRANSPORT DATA . . . . . . . . 4

3.2 BRIEF DESCRIPTION OF SIMULATED CASES .......... 5

4.0 RESULTS . . . . . . . . . . . . . . . . . 6

5.0 SUMMARY/CONCLUSIONS $\ldots \ldots \ldots \ldots$

6.0 REFERENCES $\ldots \ldots \ldots \ldots \ldots$

APPERDIX A CONCENTRATION RESULTS OF CASES 1, 5, and $6 \ldots \ldots$. . . . A.1

\section{LIST OF TABLES}

TABLE 3.1 Surmary of Flow and Transport Data . . . . . . . . . . . 4 


\section{LIST OF FIGURES}

FIGURE 2.1 Conceptual Model of 105A Mock-Up Tank Leak . . . . . . . . . 3

FIGURE 4.1 Case 2, With Effect of Tank Umbrella, Salt-Concentration (g/L) Contours from Five Days to Five Years . . . . . . . 7

FIGURE 4.2 Case 2, With Effect of Tank Umbrella, Salt-Concentration $(\mathrm{g} / \mathrm{L})$ Contours from Fifty Years to Three Hundred Years . . . 8

FIGURE 4.3 Case 3, With High Recharge, Salt-Concentration ( $/ \mathrm{L}$ ) Contours from Five Days to Five Years . . . . . . . . . . . 9

FIGURE 4.4 Case 3, With High Recharge, Salt-Concentration (g/L) Contours from Fifty Years to Three Hundred Years . . . . . . 10

FIgURE 4.5 Case 4, With No Dispersion, Salt-Concentration ( $/ \mathrm{L}$ ) Contours from Five Days to Five Years . . . . . . . . . . . . 11

FIGURE 4.6 Case 4, With No Dispersion, Salt-Concentration (g/L) Contours from Fifty Years to Three Hundred Years . . . . . . 12

FIGURE 4.7 Case 7, With No Dispersion/Double Injection, SaltConcentration $(\mathrm{g} / \mathrm{L})$ Contours from Five Years to Three Hundred Years... . . . . . . . . . . . . . . .

FIGURE 4.8 Case 7, With No Dispersion/Double Injection, SaltConcentration ( $g / L)$ Contours from Six Hundred Years to Nine Hundred Years

FIGURE 4.9 Case 7, With No Dispersion/Double Injection, Salt-

Concentration $(g / L)$ Contours at One Hundred Years in Three Dimensions

FIGURE A.1 Case 1, With No Tank Effects, Salt-Concentration (g/L) Contours from Five Days to Five Years . . . . . . . . . A.3

FIGURE A.2 Case 5, With Leak at Edge of Tank, Salt-Concentration (g/L) Contours from Five Days to Five Years . . . . . . . . . A.4

FIGURE A.3 Case 5, With Leak at Edge of Tank, Salt-Concentration ( $/ \mathrm{L}$ ) Contours from Fifty Years to Three Hundred Years . . . . . . A.5

FIGUPE A.4 Case 6, With Leak Underneath Tank, Salt-Concentration (g/L) Contours from Five Days to Five Years . . . . . . . . . A.6

FIGURE A.5 Case 6, With Leak Underneath Tank, Salt-Concentration ( $/$ /L) Contours from Fifty Years to Three Hundred Years . . . . . . A.7 


\subsection{INTRODUCTION}

The purpose of this bounding analysis was to determine bounding estimates of salt concentrations in the aquifer below the salt-tracer plume test at the 105A mockup-tank site near the inactive Semi-Works Plant in the 200 East Area. The objective was to calculate the bounding salt

concentrations and compare them to the appropriate maximum contamination level (MCL) allowed by state law (WAC 173-200), which for sodium chloride is $415 \mathrm{mg} / \mathrm{L}$ as a secondary standard. Sodium chloride (salt) is not a toxic chemical; hence, only a secondary standard exists.

The tracer test is part of the Electrical-Resistance Tomography (ERT) demonstration, which will provide an effective method of detecting tank leaks if it is shown to be successful. The basic idea of ERT method is that the electrical resistance in the soils will change enough to be detected when water with salts (electrolytes improve the electrical conductivity) infiltrate the soils, even if a high-conductance metal tank is just above the leak.

The 105A mockup tank did not have an impermeable bottom and was open at the top until the time of the test. It was assumed, at the time of the tracer test or shortly afterwards, that an impermeable bottom (concrete) would be placed at the bottom of the tank, but still remain open at the top. Hence, in this analysis, no artificial recharge is produced due to water running off a tank top, since no top is assumed.

The conceptual model is discussed in Section 2.0 with the mathematical and numerical models briefly discussed in Section 3.0. The main results are given in Section 4.0 with the conclusions drawn in Section 5.0.

These calculations were made before the tracer test. A similar set of calculations will be performed after the tracer test assuming more details concerning leak location and soil properties are available. The tracer test could be used to validate or confirm the modeling methodology/capability of plumes in the vadose zone at the Hanford site. 
WHC-SD-WM-TI-646, Rev. 0

\subsection{CONCEPTUAL MODEL}

Since unsaturated hydraulic data is not available at the test site and this analysis was bounding in purpose, the hydraulic data from the grout site about $1 \mathrm{~km}$ east of the tracer-test site was used. This hydraulic data was well characterized for the Grout Performance Assessment (Kincaid et al. 1993, Piepho 1994). One bore-hole, 299-E27-1, near the test site indicated that the aquifer was 281 feet below the ground surface in December 1993. The conceptual model, shown in Figure 2.1 , assumed $83 \mathrm{~m}$ of vadose zone above the aquifer, and the top $7.25 \mathrm{~m}$ of aquifer was also included in the model. No regional flow of water in the aquifer was included in the model in order to be conservative. It is conservative to exclude the horizontal regional water flow since it would add fresh water to the salt plume and lower the salt's concentration. Hence, in the conceptual model, water only flows vertically through the bottom (not the left or right) boundary with a flux equal to the recharge on the top boundary. Basically, only the top part of the aquifer in included in the model since the peak salt concentrations would have to occur at the top before the plume gets diluted with more aquifer water.

The vadose zone was modeled in three dimensions to be more realistic. A realistic bounding analysis was desired. The vadose zone modeling was conservative in the sense that much of the anisotropy, especially moisturedependent anisotropy, was excluded (the horizontal conductivities were assumed to be only a factor of 10 larger than the vertical conductivities). Also, dispersion effects were excluded from a couple of cases for more conservatism. Vadose zone anisotropy and dispersion would have the effect of spreading the plume out, especially in the horizontal direction, and, hence, diluting the salt plume more in the vadose zone, which would lower the salt concentration in the aquifer later.

The most conservative aspect of the model was the fact that the aquifer water was stationary in the horizontal direction. If the horizontal flow of the aquifer were included, the salt concentrations in the aquifer would be even lower than calculated here.

The location of the tank leak was placed on the upper left boundary (see Figure 2.1) for most of the simulations. Some simulated cases placed the tank leak to be in other locations within the model's grid domain in order to see the effects that the tank, which was assumed to be closed on the bottom and open on the top, would have on the plume. Before the tracer test, the tank was open on both the top and bottom, which would mean that for recharge purposes, the tanh was not really there. At the time of the tracer test, the tottom of the tank was assumed to be closed off so that rain water could not infiltrate below the tank. 
WHC-SD-WM-TI-646, Rev. 0

FIGURE 2.1 Conceptual Model of 105A Mock-Up Tank Leak

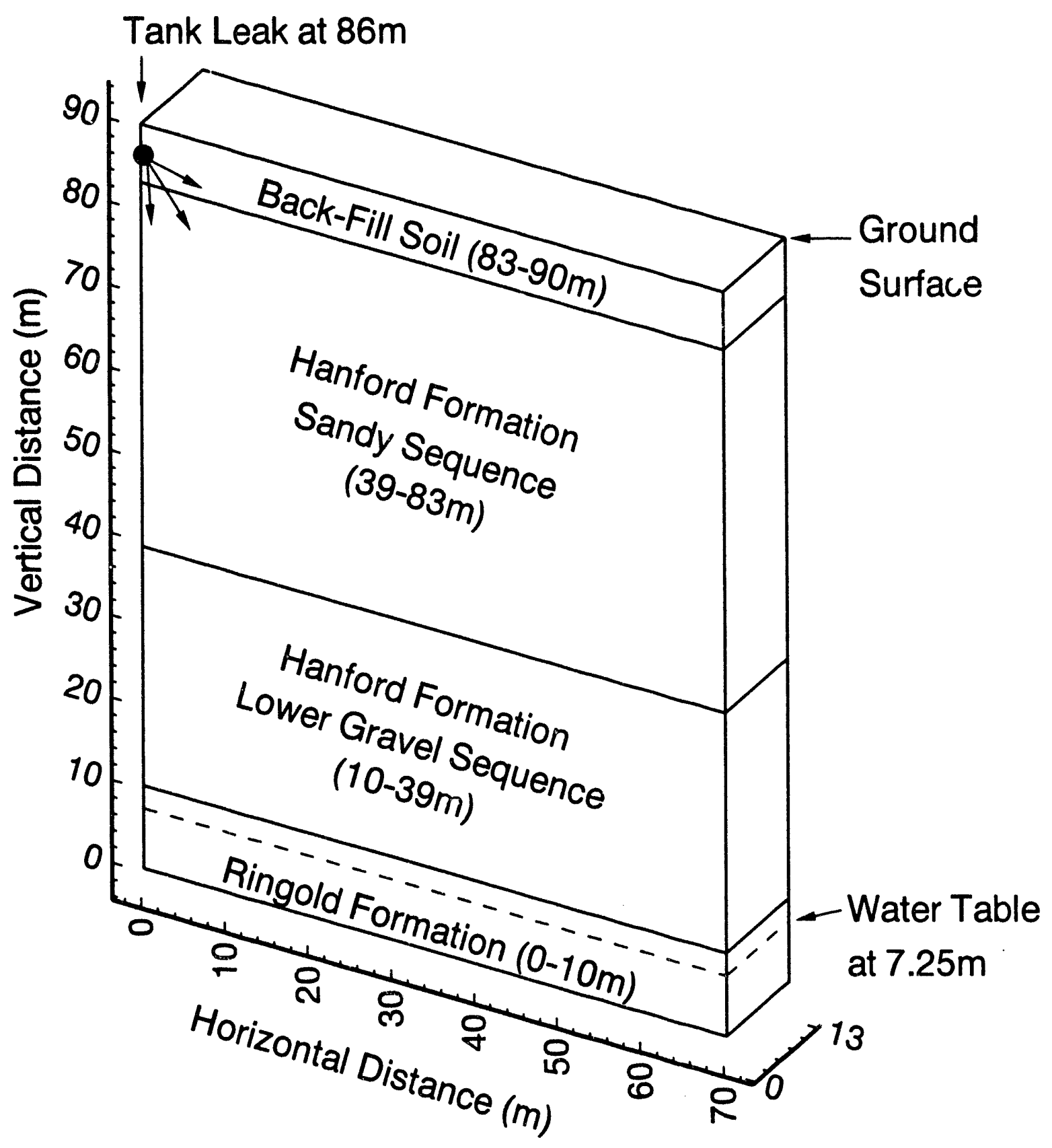


WHC-SD-WM-TI-646, Rev. 0

\subsection{MATHEMATICAL/NUMERICAL MODEL}

The PORFLOW code (Runchal and Sagar, 1992), version 2.394gr, was used to simulate the salt plume resulting from the 105A mockup tank leak test.

PORFLOW solves a set of coupled equations for fluid velocities, pressure and concentrations of chemical species in variably saturated (both unsaturated and saturated) porous media. These equations are based on the conservation principles of continuum mechanics, except that the Darcy's equations are used in place of the Navier-Stokes equations.

The numerical grid was three-dimensional with 36 nodal points in the $x-$ direction, 15 nodal points in the $y$-direction (horizontal), and 83 nodal points in the z-direction (vertical). As shown in Figure 2.1, the vertical axis consisted of $90 \mathrm{~m}$ of soils with the bottom $7.25 \mathrm{~m}$ being the aquifer and the top $82.75 \mathrm{~m}$ being the vadose zone. The tank leak was assumed to be at 86 meters above the bottom grid boundary or about $79 \mathrm{~m}$ above the aquifer.

\subsection{HYDRAULIC (FLOW) AND TRANSPORT DATA}

The hydraulic and transport data, which was first used in the Grout Performance Assessment (Kincaid et al. 1993, Piepho 1994), are shown in Table 3.1. Dispersion was included in some of the cases and the dispersion coefficients are listed in Table 3.1.

TABLE 3.1 Summary of Flow and Transport Data

\begin{tabular}{|c|c|c|c|c|c|c|c|}
\hline \multicolumn{7}{|c|}{ Hydraulic/Transport Parameters } \\
\hline \hline Material & $\begin{array}{c}\mathbf{K}_{\mathrm{s}} \\
(\mathrm{cm} / \mathrm{s})\end{array}$ & $\theta_{\mathrm{s}}$ & $\theta_{r}$ & $\begin{array}{c}\alpha^{\alpha} \\
\left(\mathrm{cm}^{-1}\right)\end{array}$ & $n$ & $\begin{array}{c}\alpha_{L} \\
(\mathrm{~cm})\end{array}$ & $\begin{array}{c}\alpha_{r} \\
(\mathrm{~cm})\end{array}$ \\
\hline \hline Backfill Soil & $3.00 \mathrm{E}-2$ & 0.371 & 0.045 & 0.0683 & 2.080 & 100 & 10 \\
\hline $\begin{array}{c}\text { Hanford Formation } \\
\text { Sandy Sequence }\end{array}$ & $1.55 \mathrm{E}-3$ & 0.420 & 0.023 & 0.1943 & 1.868 & 300 & 30 \\
\hline $\begin{array}{c}\text { Hanford Formation } \\
\text { Gravel sequence }\end{array}$ & $2.73 \mathrm{E}-4$ & 0.358 & 0.021 & 0.0290 & 1.613 & 400 & 40 \\
\hline Ringold Formation & $2.42 \mathrm{E}-6$ & 0.498 & 0.028 & 0.0176 & 1.338 & 50 & 5 \\
\hline
\end{tabular}

In the table, the parameters are defined as follows:

$K_{s}=$ Saturated hydraulic conductivity $(\mathrm{cm} / \mathrm{s})$,

$\theta_{s}=$ Saturated moisture content (i.e., the porosity),

$\theta_{r}=$ Residual moisture content,

$\alpha^{r}=$ Moisture retention/relative permeability curve-fitting parameter (van Genuchten 1978) $\left(\mathrm{cm}^{-1}\right)$,

$\mathrm{n}$ = Moisture retention/relative permeability curve-fitting parameter (van Genuchten 1978),

$\alpha_{1}=$ Longitudinal dispersion coefficient $(\mathrm{cm})$,

$\alpha_{T}=$ Transverse dispersion coefficient $(\mathrm{cm})$. 
In addition to above parameters, a diffusion coefficient of $2.5 \mathrm{E}-5 \mathrm{~cm}^{2} / \mathrm{s}$ was assumed for salt in free water. The Scheidegger dispersion model (Scheidegger 1961) was used for most of the cases except for the two nodispersion cases which used the Kemper diffusion model (Kemper and van Schaik, 1966).

\subsection{BRIEF DESCRIPTION OF SIMULATED CASES}

Case 1: Leak is at left-front edge of grid (as shown in Figure 2.1) and the flow and transport data is shown in Table 3.1. The leak rate was 2000 galions (divided by four in the model since only quadrant of soil is modeled assuming symmetry) over five days. The recharge is one (1) $\mathrm{cm} / \mathrm{yr}$ across the entire top ground surface.

Case 2: The tank is moved intc the model domain (no recharge gets through the tank which is assumed to catch all precipitation above the tank), and the leak is at right side of tank. The leak rate was 2000 jallons (divided by two in the model since only one half of soil is modeled assuming symmetry) over five days.

Case 3: $\quad$ Same as Case 1 except that the recharge is increased to five (5) $\mathrm{cm} / \mathrm{yr}$ from one (1) $\mathrm{cm} / \mathrm{yr}$.

Case 4: Same as Case 3 except that the dispersion coefficients were set to zero; in other words, only diffusion of the salt was included in the transport model which results in a more concentrated plume. Dispersion coefficients will tend to spread out the plume more. This case, by excluding dispersion, is very conservative.

Case 5: The tank is moved into the midule right part of model domain. The leak is on the left side of tank. The leak was 2000 gallons (divided by two in the model since only one half of the soil is modeled assuming symmetry) over five days.

Case 6: Same as Case 5 except that the leak is moved slightly under the left side of tank so that no recharge hits the leak directly from above.

Case 7: Same as Case 4, the most conservative one with no dispersion, except that the leak rate was increased to 4000 gallons over 10 days. Basically, the leak rate is the same as in Case 4 , but the time of the leak rate was extended from five days to 10 days resulting in twice as much salt water being leaked. This case produced the highest salt concentrations due to the conservative assumption of no dispersion and to the double injection of salt water. 
WHC-SD-WM-TI-646, Rev. 0

\subsection{RESULTS}

The concentration results of the four main cases (Cases $2,3,4$ and 7 ) are presented here, and the graphical concentration results of the other cases are shown in Appendix A. Case 2 includes the impermeable tank effects on the recharge and plume. Case 3 is the high recharge case and does not include the tank effects (i.e., the leak is at the left-front boundary; see Figure 1.0). Case 4 is the conservative no-dispersion case and Case 7 is the same as Case 4 except that it includes a double salt injection of 4000 gallons instead of 2000 gallons. Since Case 7 includes no dispersion effects and has the double salt injection, it is the most conservative case; that is, the salt concentrations near the aquifer are the highest for Case 7.

Case 2 salt concentrations at different time (five days to 300 years) are shown in Figures 4.1 and 4.2. The salt concentrations have units of $\mathrm{g} / \mathrm{L}$ in the figures; hence, to convert to $\mathrm{mg} / \mathrm{L}$ for comparison to a $\mathrm{MCL}$, one needs to multiply the numbers in the figures by 1000 . At 300 years after the start of the test, the salt concentration in the vadose zone is basically below $50 \mathrm{mg} / \mathrm{L}$ (the $0.05 \mathrm{~g} / \mathrm{L}$ contour is fairly small). Since the salt plume has spread so much in the vadose zone, the concentration in the aquifer will nover go above the salt MCL in future years.

Case 3 salt concentrations, with the effects of a high recharge of 5 $\mathrm{cm} / \mathrm{yr}$ instead of $1 \mathrm{~cm} / \mathrm{yr}$, are shown in Figures 4.3 and 4.4 for various points in time ranging from five days to 300 years. The higher recharge causes the salt plume to move downward faster than the plume in Case 2. Two hundred years after the start of the tracer test, the plume center has already reached the aquifer. The salt concentration in the aquifer at 200 years is around 10 $\mathrm{mg} / \mathrm{L}$ which is way below the salt $\mathrm{MCL}$ of $415 \mathrm{mg} / \mathrm{L}$. The effects of the tank, which will act to slow down the plume due to not letting some water infiltrate, are not included in Case 3.

Case 4 salt concentrations, with the conservative effects of no dispersion coefficients, are shown in Figures 4.5 and 4.6. After 300 years, the plume center has reached almost half way down the vadose zone and has a concentration of about $500 \mathrm{mg} / \mathrm{L}$ in the vadose zone. Although not shown graphically, the plume center reaches the aquifer in about 800 years and has a concentration of $40 \mathrm{mg} / \mathrm{L}$.

Case 7 salt concentrations, which is the same as Case 4 but has twice as much salt water (4000 gallons) injected, are shown in Figures 4.7 and 4.8 for times ranging from five years to 900 years. The plume center is shown to reach the aquifer (bottom 7.5 meters) in Figure 4.8 at 800 years and has a concentration less than $100 \mathrm{mg} / \mathrm{L}$ (actually $90 \mathrm{mg} / \mathrm{L}$ from a more detailed print out). At 900 years, the concentrations are lower as the $0.1 \mathrm{~g} / \mathrm{L}$ contour disappears in Figure 4.8 after 900 years from the start of the tracer test. Even in this conservative case, the maximum salt concentrations in the aquifer are w'ell below the salt MCL of $415 \mathrm{mg} / \mathrm{L}$. The salt concentration contours are shown in three dimensions in Figure 4.9 at 100 years. The 30 graph clearly shows the quadrant of soil included the model and shows that the maximum salt concentration is realized on the front-most plane in the 3D domain. This is why only the front plane concentration contours are shown in the previous 2D graphs. 


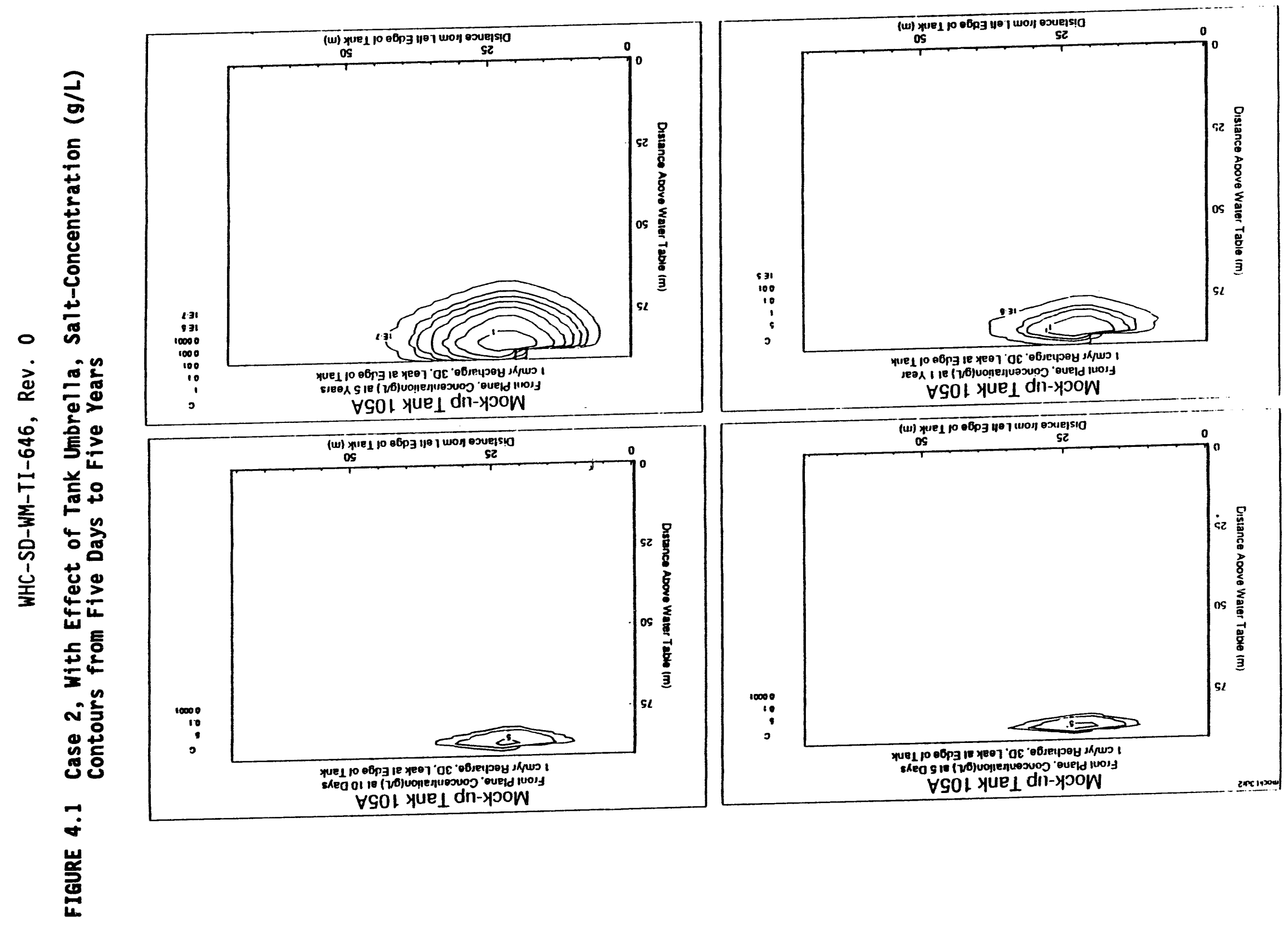

N 

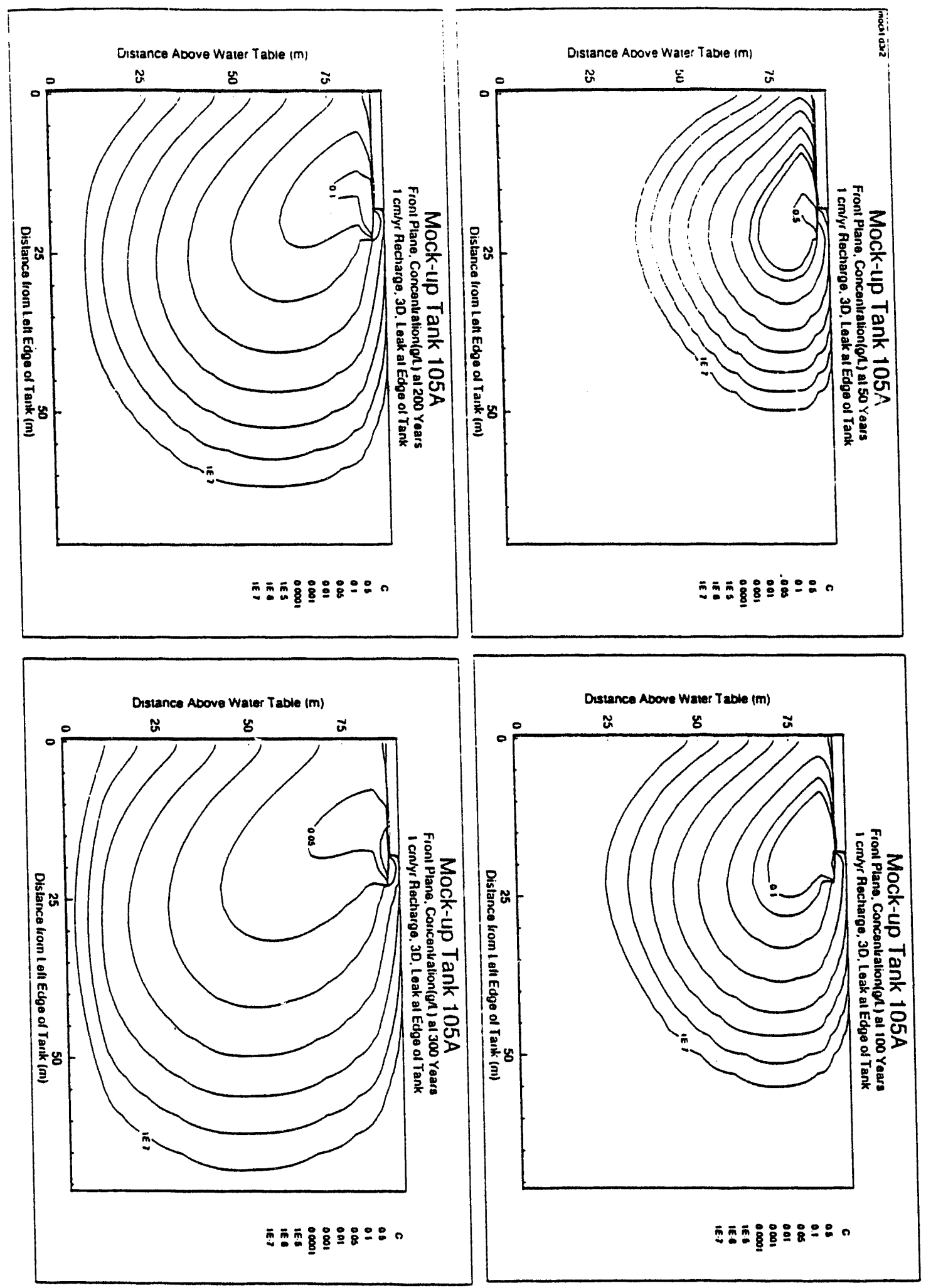

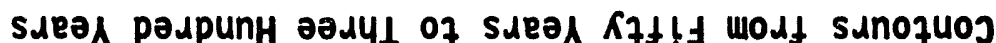

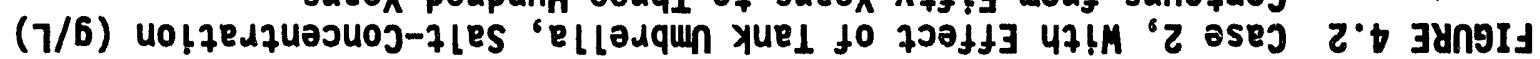


WHC-SD-WM-TI-646, Rev. 0

FIgURE 4.3 Case 3, With High Recharge, Salt-Concentration ( $g / L$ ) Contours from Five Days to Five Years

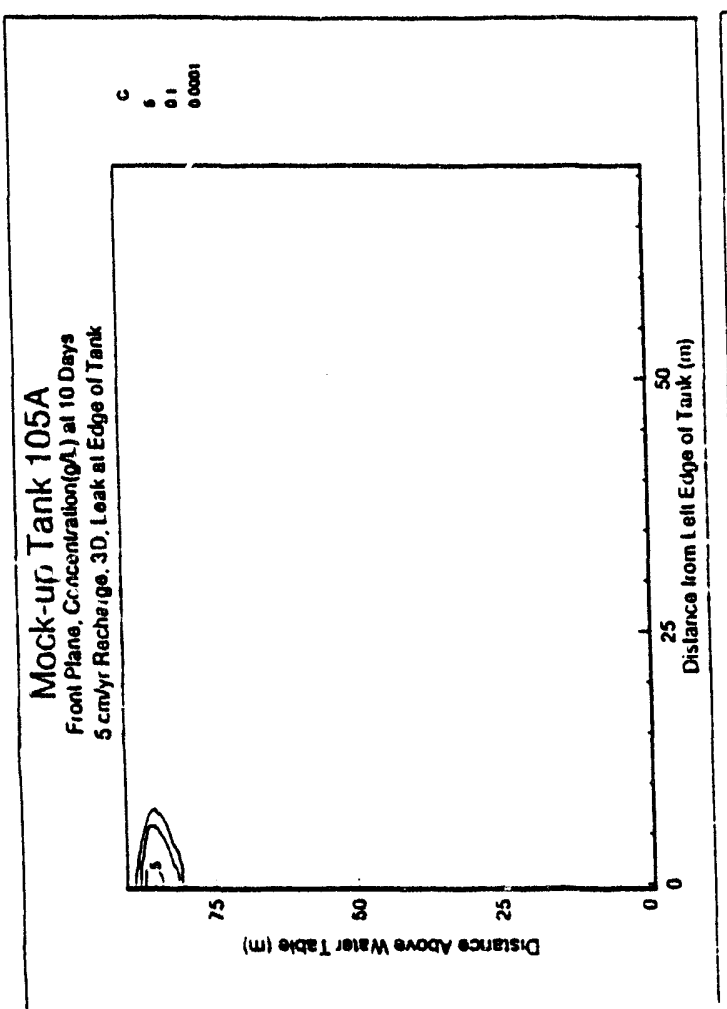

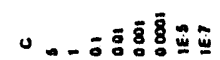
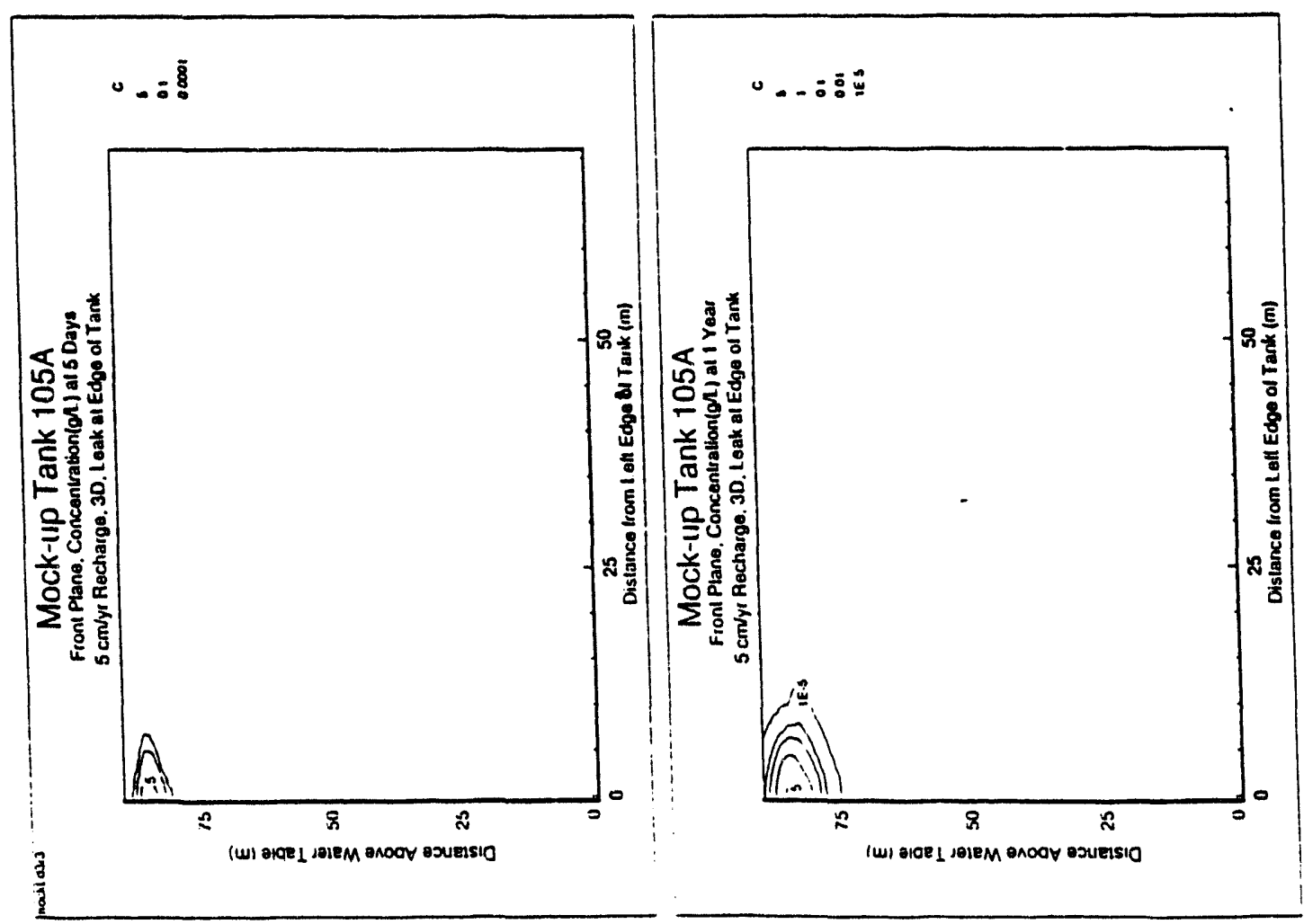

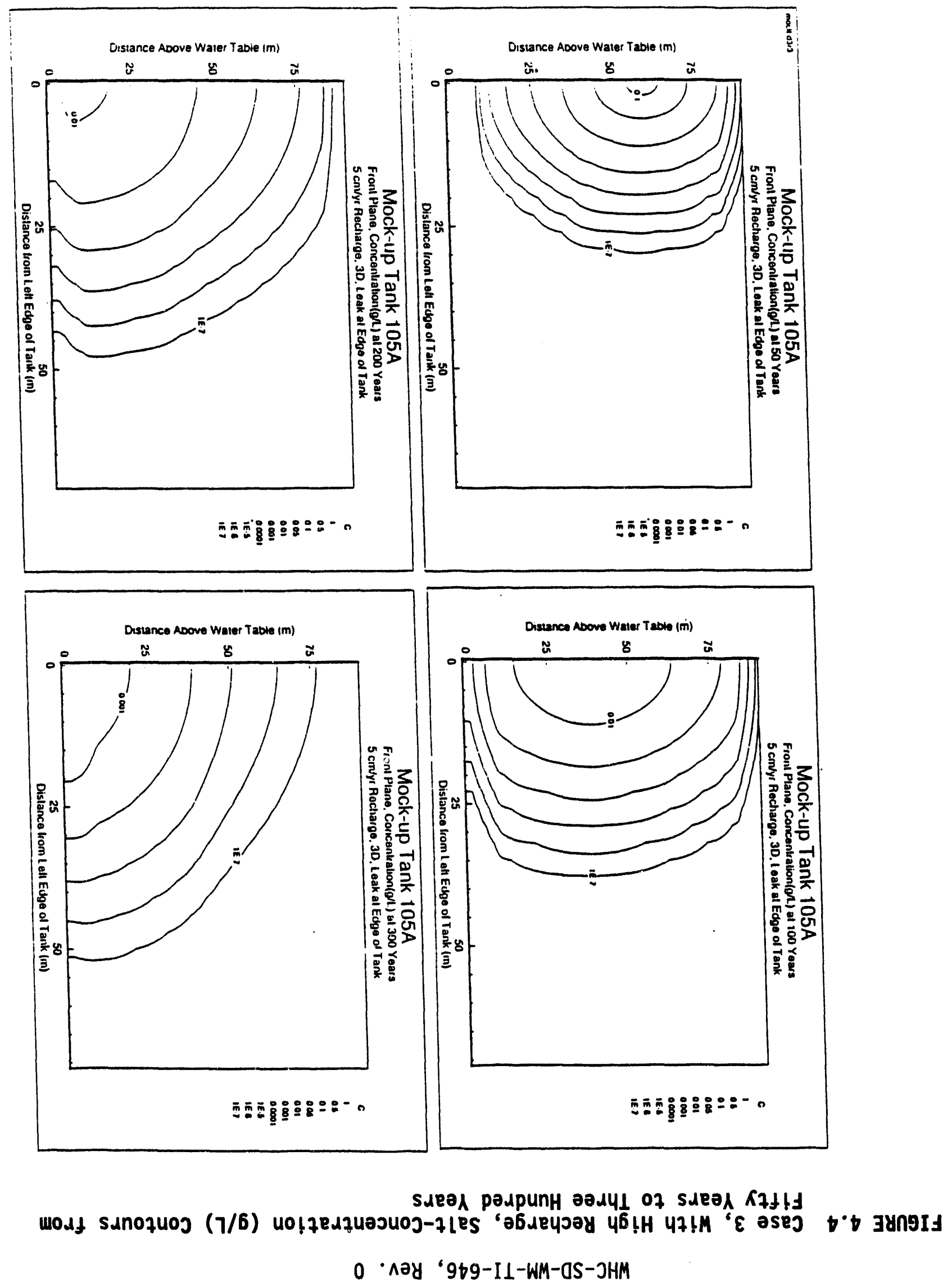

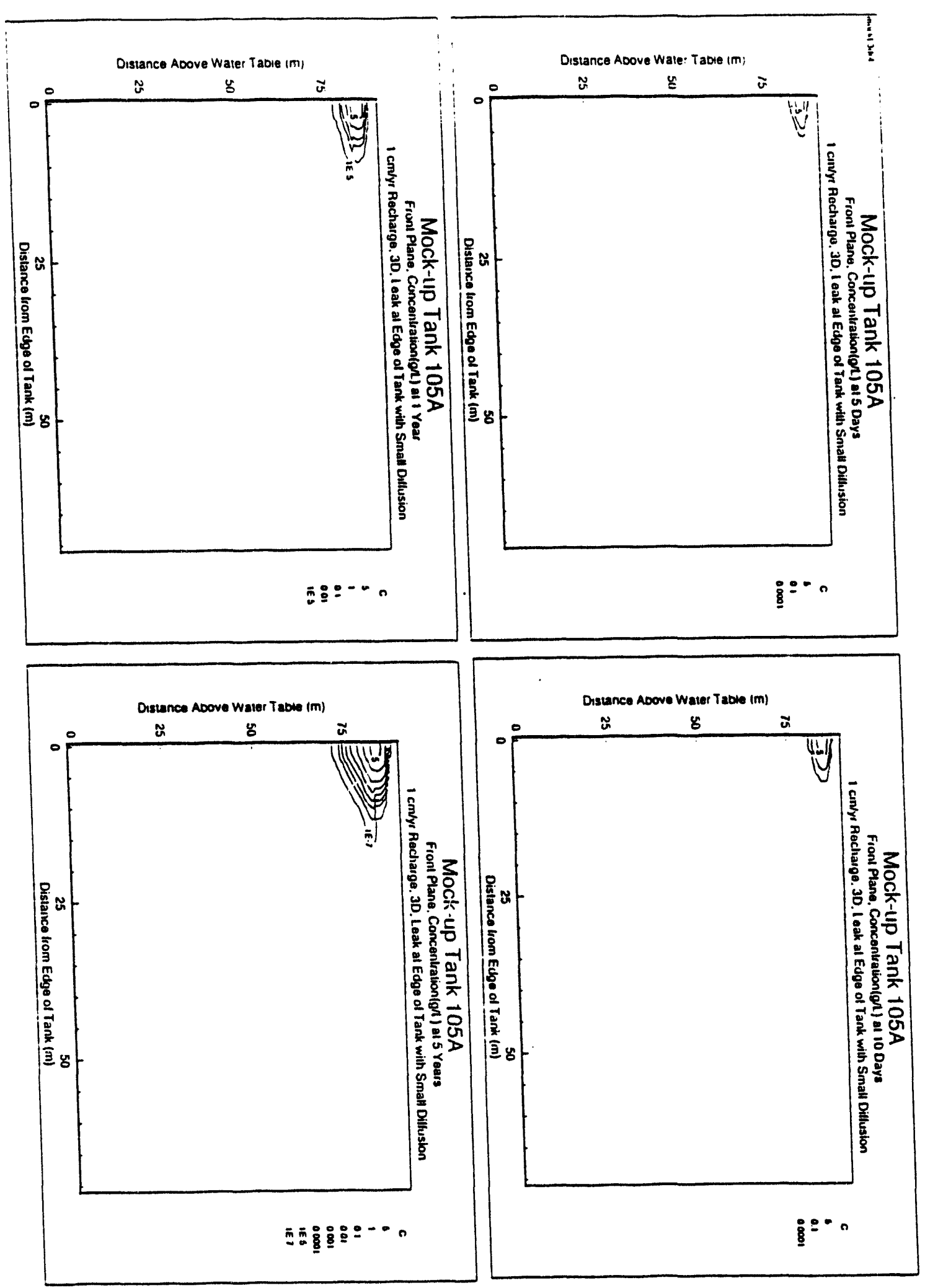

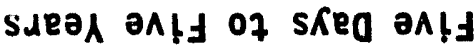

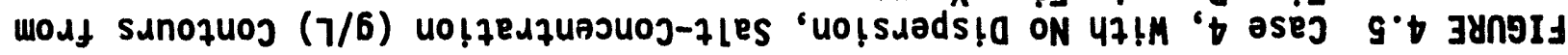

$0 \cdot \wedge$ • ' 9 เ9-I1-WM-OS-JHM 
WHC-SD-WM-TI-646, Rev. 0

FIGURE 4.6 Case 4, With No Dispersion, Salt-Concentration ( $g / L)$ Contours from Fifty Years to Three Hundred Years
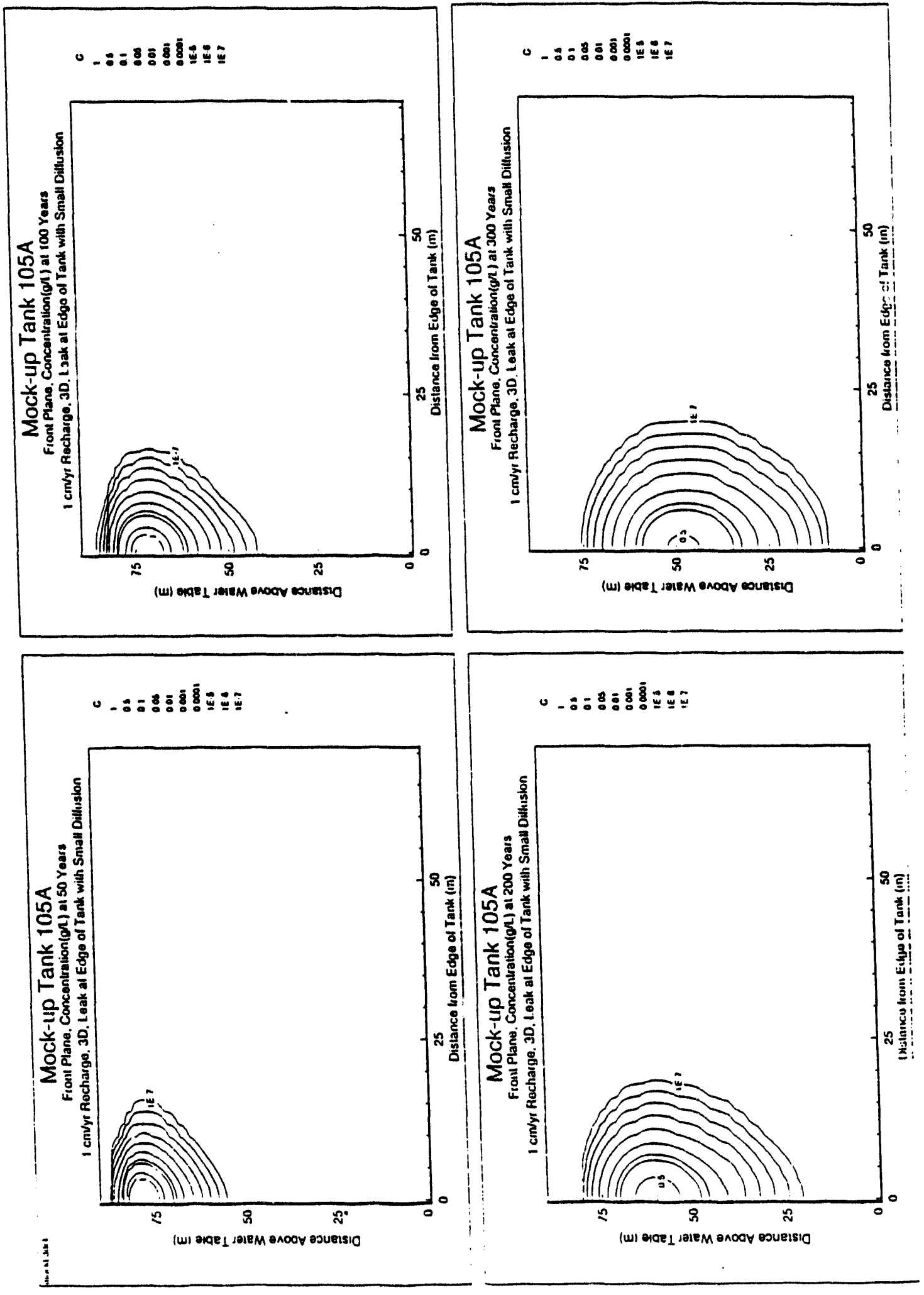

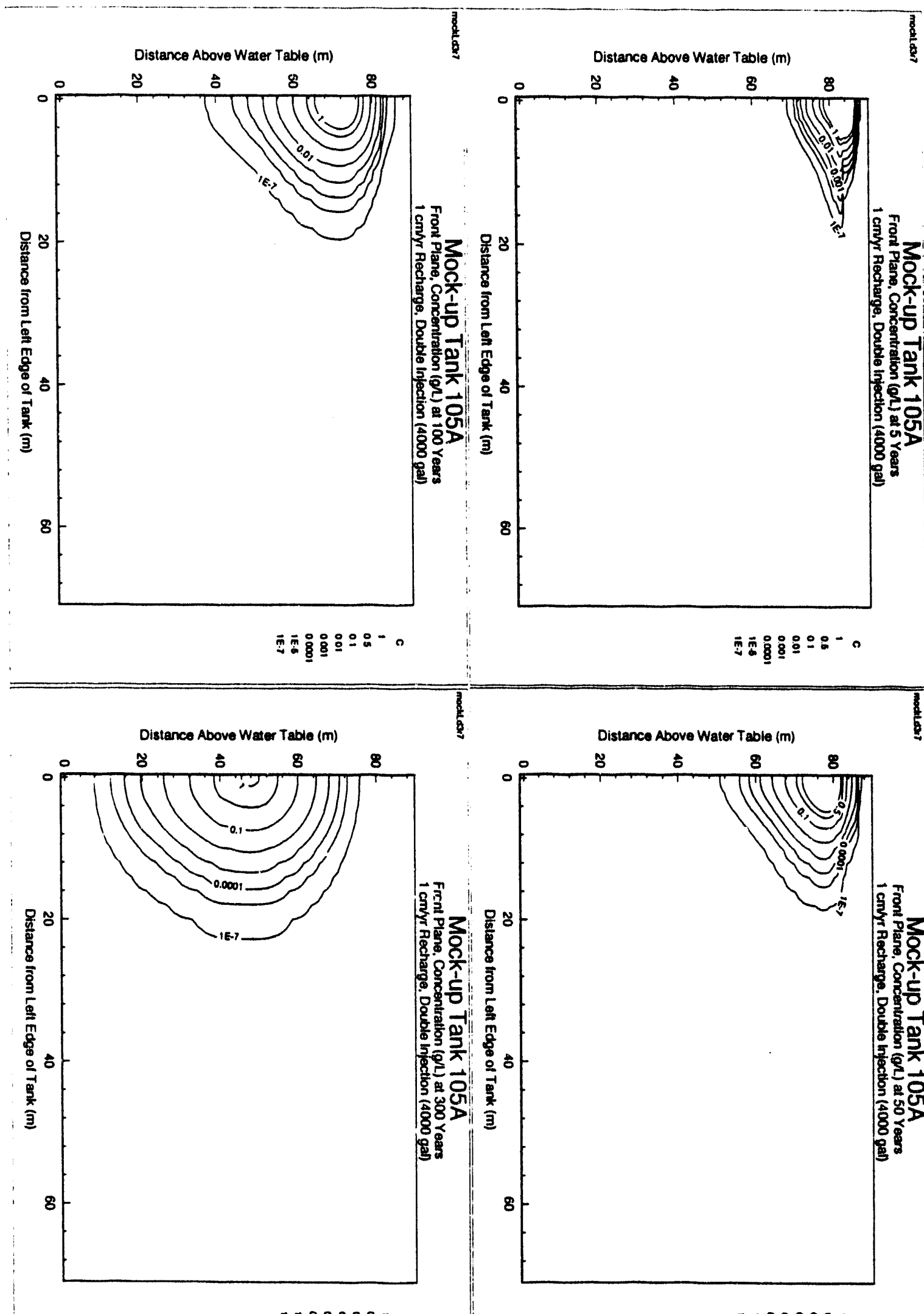

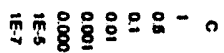

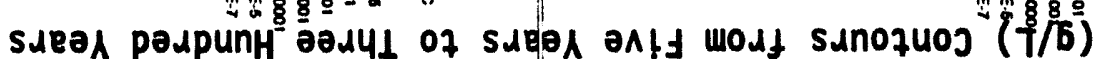

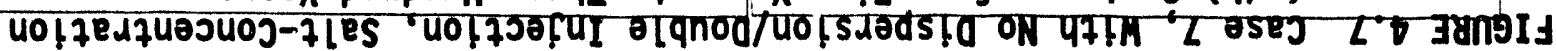

0 •^әу '9†9-II-WM-OS-כHM 
WHC-SD-WM-TI-646, Rev. 0

FIGURE 4.8 Case 7, With No Dispersion/Double Injection, Salt-Concentration

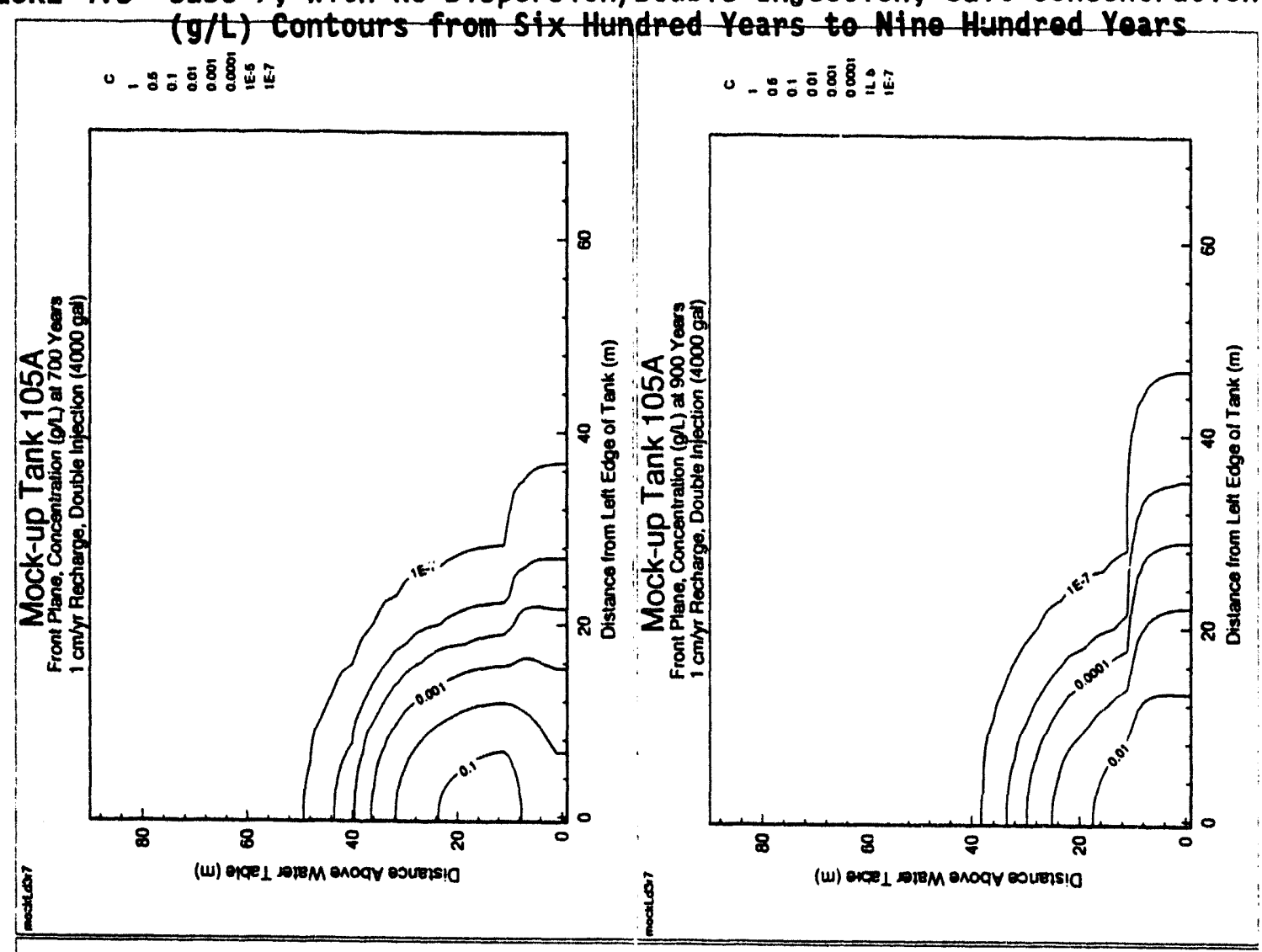

๑ _. _

๑ _. _.

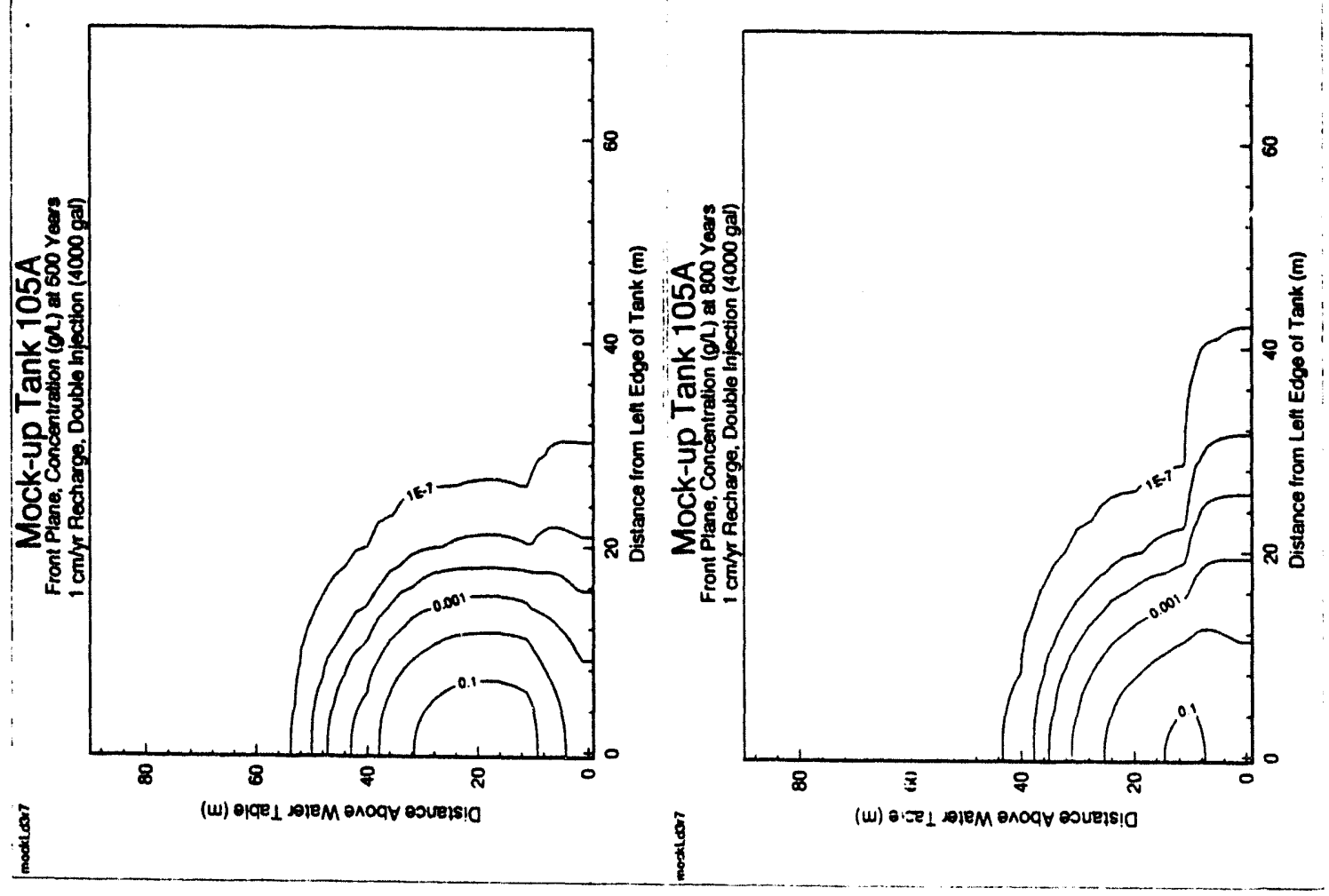


WHC-SD-WM-TI-646, Rev. 0

FIGURE 4.9 Case 7, With No Dispersion/Double Injection, Salt-Concentration $(\mathrm{g} / \mathrm{L})$ Contours at One Hundred Years in Three Dimensions

Mock-up Tank 105A

Salt Concentration ( $\mathrm{g} / \mathrm{L})$ at 100 Years

$1 \mathrm{~cm} / \mathrm{yr}$ Recharge, Double Injection (4000 gal)

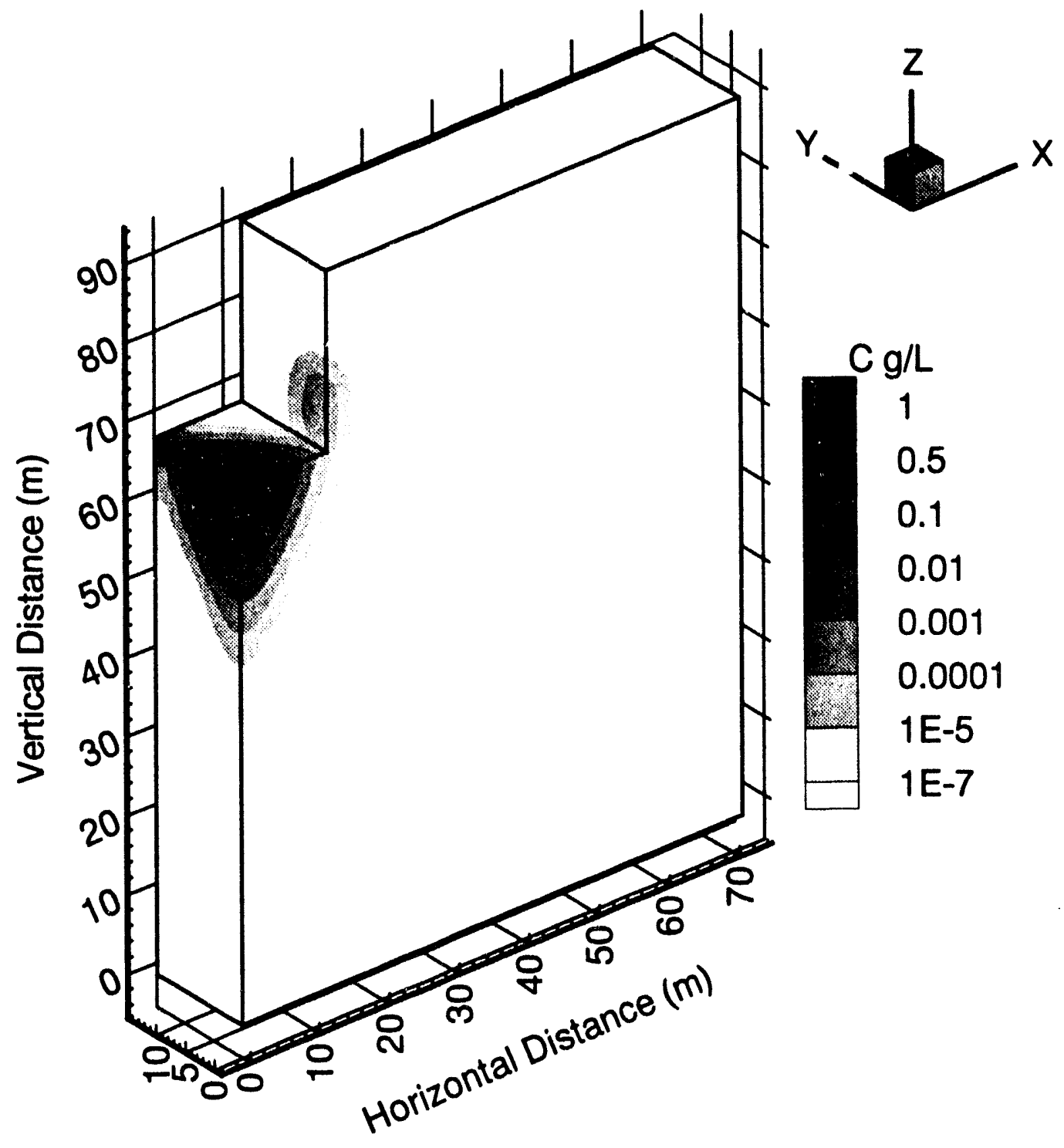


WHC-SD-WM-TI-646, Rev. 0

\subsection{SUMMARY/CONCLUSIONS}

The simulated results with one source injection but with different tank and source locations, showed that the maximum concentration of salt in the vadose zone (unsaturated zone) reduces from $7000 \mathrm{mg} / \mathrm{L}$ initially to $10 \mathrm{mg} / \mathrm{L}$ in about 300 years after injection for most of the cases. It would be even lower in the aquifer, instead of the vadose zone, where the secondary standard applies, at later times. For the high-recharge $(5 \mathrm{~cm} / \mathrm{yr})$ case, the maximum salt concentration also reduces to $10 \mathrm{m!l} / \mathrm{L}$, but the time of the maximum, around 100 years after the injection, is much sooner than the lower recharge $(1 \mathrm{~cm} / \mathrm{yr})$ cases. This is because the higher recharge causes higher water velocities which results in smaller travel times for the salt plume. The largest maximum salt concentration in the vadose zone is realized for the case that excluded dispersion effects. Excluding dispersion effects is very conservative since dispersion is known to exist and known to spread out the plume, resulting in lower concentrations. Even in this conservative nodispersion case, the resulting maximum salt concentration of $40 \mathrm{mg} / \mathrm{L}$ in the aquifer at 800 years is less than the $\mathrm{MCL}(415 \mathrm{mg} / \mathrm{L})$ for salt in drinking water (aquifer water).

One case was run which was the identical to the conservative nodispersion case except that a second injection of 2000 gallons (7570 liters) was included in the simulation. For this conservative two-injection case, the maximum salt concentration is about $90 \mathrm{mg} / \mathrm{L}$ in the top part of the aquifer 800 years after the injections. Based on this case, the amount leaked during the test could be increased to 6000 to 8000 gallons (perhaps 16,000 gallons) easily without exceeding the salt MCL. The flow rate in the aquifer, which was zero in this analysis, would probably need to be determined and used for leakages larger than 8000 to 16,000 gallons in order to show that these larger leaks would also result in an acceptable salt $\mathrm{MCL}$.

The possible effect of the salt plume on any existing radionuclides in nearby soils was not included in this analysis. However, since the inventory of radionuclides in nearby soils is expected to be very small and the water travel time of the injection source(s) is greater than 300 years, short-lived radionuclides such as ${ }^{106} \mathrm{Ru},{ }^{90} \mathrm{Sr}$, and ${ }^{137} \mathrm{Cs}$, would decay away before reaching the aquifer. Furthermore, the large amount of water (more than one billion liters) that was discharged into the 216-C-9 pond would have transported most of the radionuclides to the aquifer already. In any case, the salt-water injections are expected to have negligible effects on the small amounts of any radionuclides that may be present near the 105A mock-up tank.

In summary, the tracer test with only 4000 gallons (perhaps up to 16,000 gallons) is not expected to ever produce salt concentrations above its $M C L$ in the aquifer and is expected to have negligible impact on the small amounts of residual radionuclides in nearby soils.

More simulations with the PORFLOW code should be performed after the tracer test assuming more knowledge of the test and soil properties is available. The test could be used to validate the Hanford modeling methodology/capabilities of plumes in the vadose zone. 


\subsection{REFERENCES}

Kemper, W. 0. and J. C. van Schaik, 1966. Diffusion of Salts in Clay-Water Systems, Soil Soc. Am. Proc. 30: pp. 534-540.

Kincaid, C. T., J. W. Shade, G. A. Whyatt, M. G. Piepho, K. Rhoads, J. A. Voogd, J. H. Westsik, Jr., M. D. Freshley, K. A. Blanchard, and B. G. Lauzon, 1993. Performance Assessment of Grouted Double Shell Tank Wastes Disposal at Hanford, WHC-SD-WM-EE-004, Rev. 0, Westinghouse Hanford Company, Richland, Washington.

Piepho, M. G., 1994. The Grout Performance Assessment Results for the Base, Benchmark. Sensitivity, and Degradation Cases, WHC-SD-WM-TI-561, Westinghouse Hanford Company, Richland, Washington.

Runchal, A. K. and B. Sager, 1992; PORFLOW: A Model for Fluid Flow, Heat and Mass Transport in Multi-fluid, Multi-phase Fractured or Porous Media. Users Manual, Version 2.4, ACRi/106/Rev. G, Analytic and Computational Research, Inc., Los Angeles, CA.

Scheidegger, A. E., 1961. General Theory of Dispersion in Porous Media, J. Geophys. Res., 66, pp. 3273-3278.

van Genuchten, M. Th., 1978; Calculating the Unsaturated Hydraulic Conductivity with a New Closed-Form Analytic Model, Report 78-WR-08, Water Resources irogram, Dept. of Civil Engineering, Princeton University, Princeton, NJ.

WAC 173-200. Water Quality Standards for Ground Waters of the State of Washington, Section 40, Washington State Department of Ecology, O1ympia, Washington, December 1, 1990. 
WHC-SD-WM-TI-646, Rev. 0

\section{APPENDIX A}

CONCENTRATION RESULTS OF CASES 1, 5, and 6

A. 1 
These Cases (1, 5, and 6) were not crucial in determining the maximum salt MCL in the aquifer, but are of interest to see the different results due to different leak locations.

Case 1 includes no effects of the tank with the leak at the top leftfront part of the model domain and the tank is not even in the model. The salt concentration contours are shown out to five years in Figure A.1. Since the concentrations are smaller than Case 4 and Case 7 concentrations, additional concentrations are not shown.

Case 5 includes the effects of the tank and the leak is at the far left side of the tank. Half of the leak is out from the left side of the tank and the other half of the leak modeled is under the left side of the tank. The results (shown in Figure $A .2$ and $A .3$ from five days to 300 years) are basically the same as Case 1 results with the only differences due to the different tank/leak location.

Case 6 is the same as case 5 except that the leak is placed under the left side of tank so the effects of the tank should be even greater. The concentrations for Case 6 are shown in Figures A.4 and A.5 and they are not much different than those from Case 5 . The $0.05 \mathrm{~g} / \mathrm{L}$ contour is narrower in Case 6 than in Case 5 due to the tank effects, but the effect is very small. The concentration contours for Case 6 are basically the same as those from Case '.. 

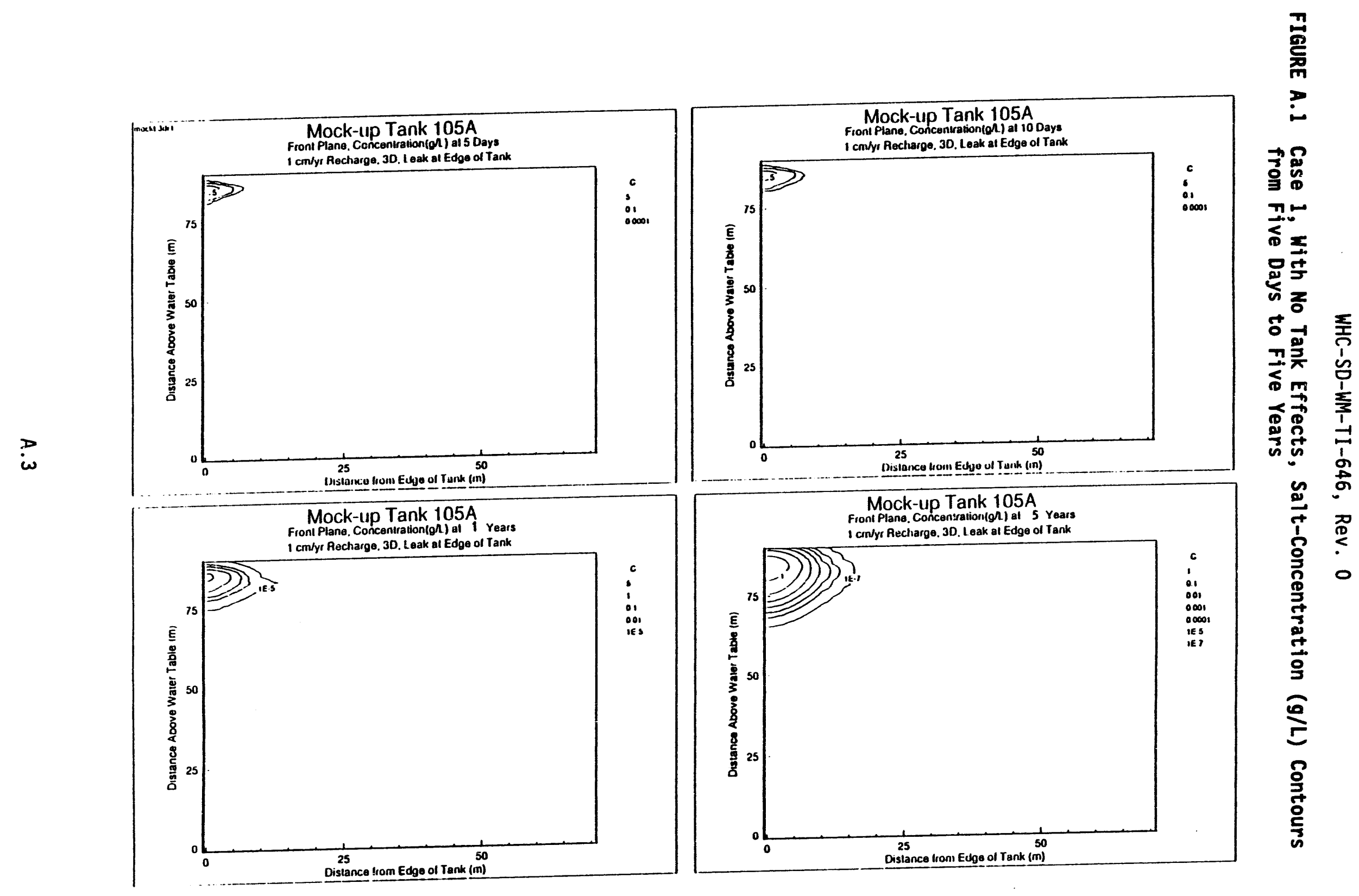

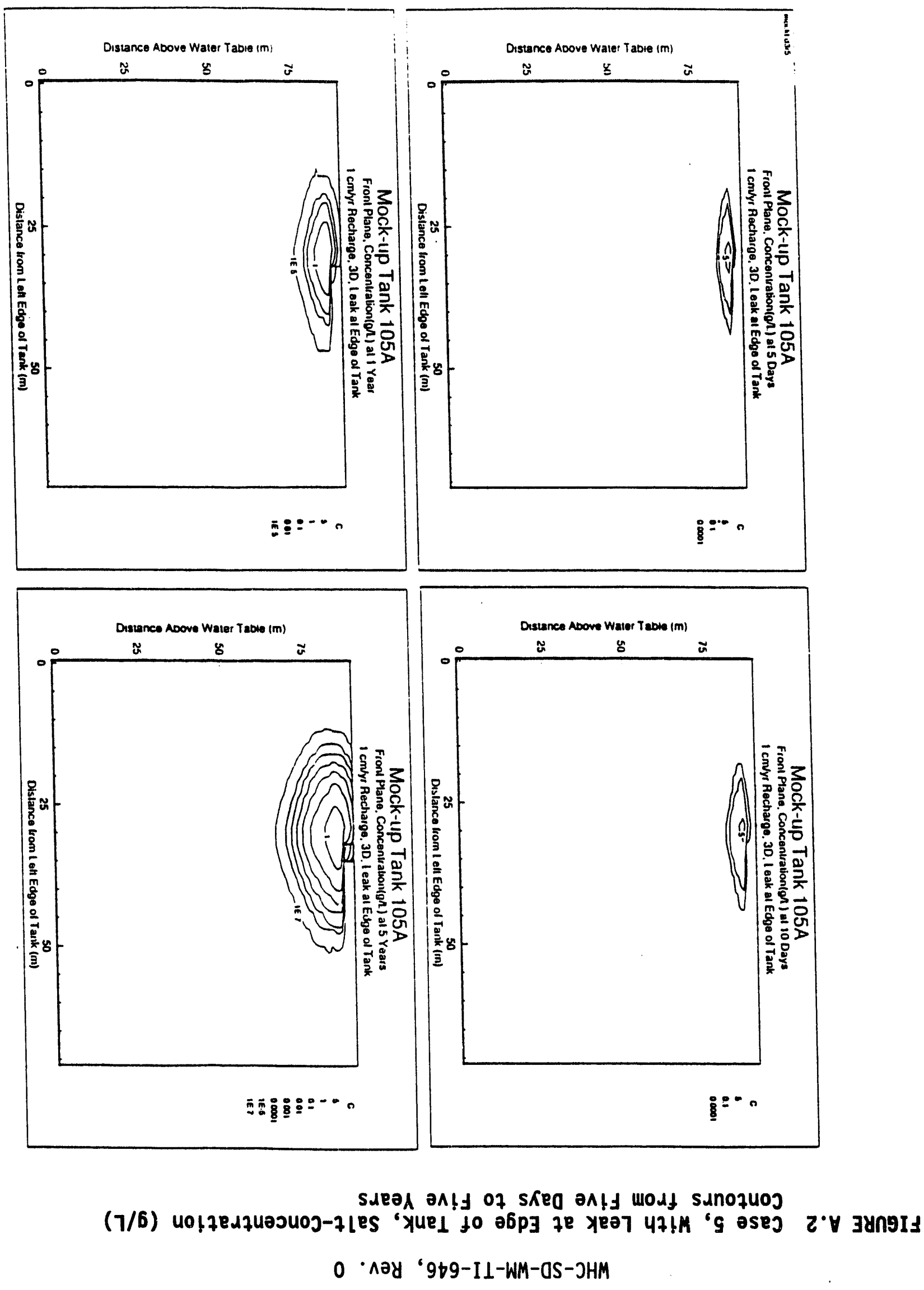
WHC-SD-WM-TI-646, Rev. 0

FIGURE A.3 Case 5, With Leak at Edge of Tank, Salt-Concentration ( $\mathrm{g} / \mathrm{L}$ ) Contours from Fifty Years to Three Hundred Years
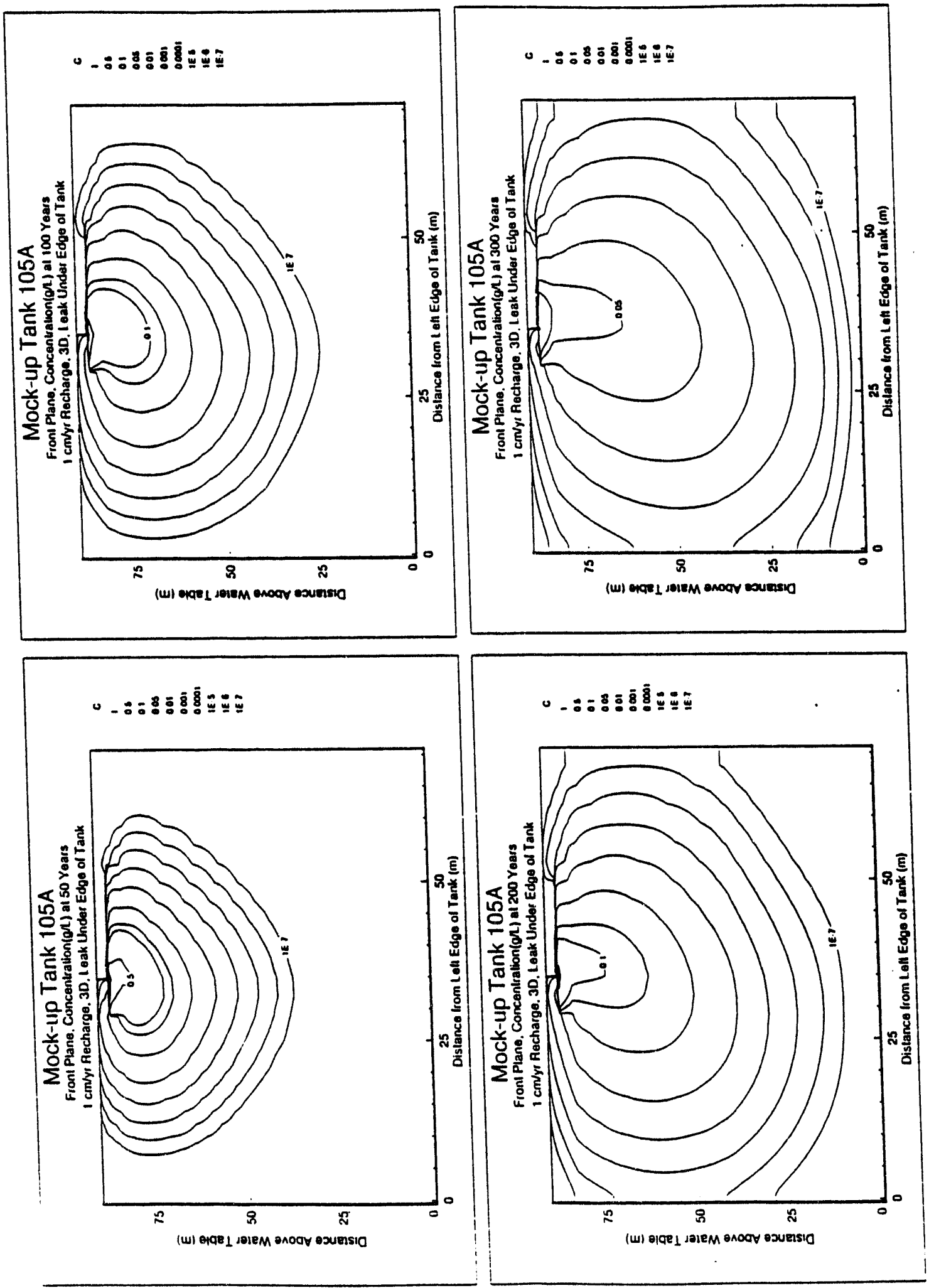

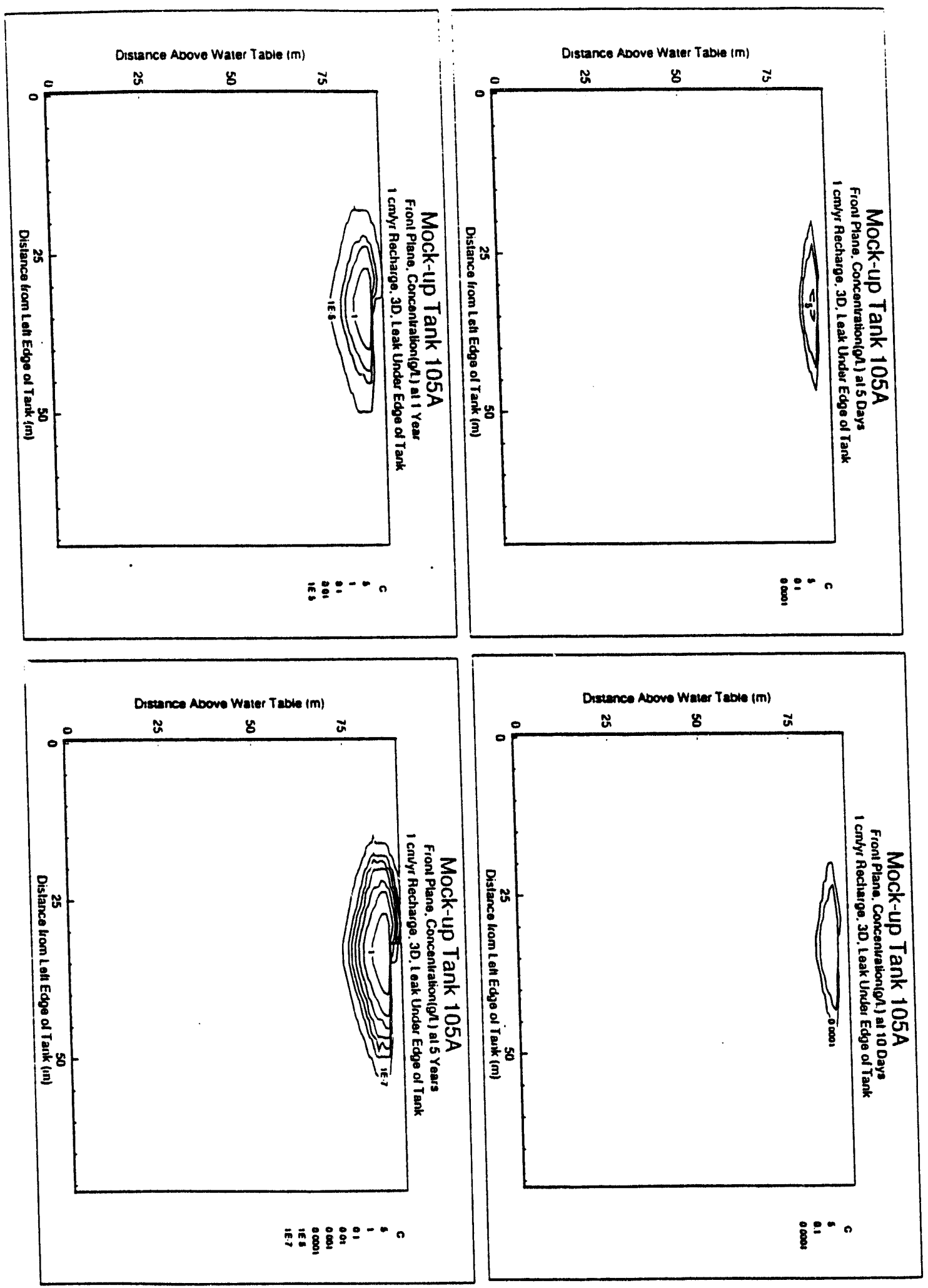

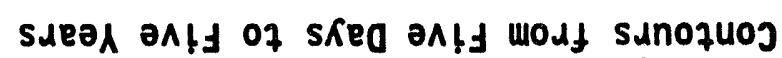

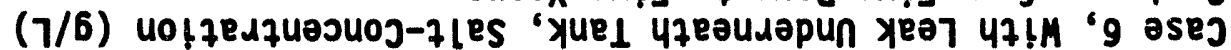



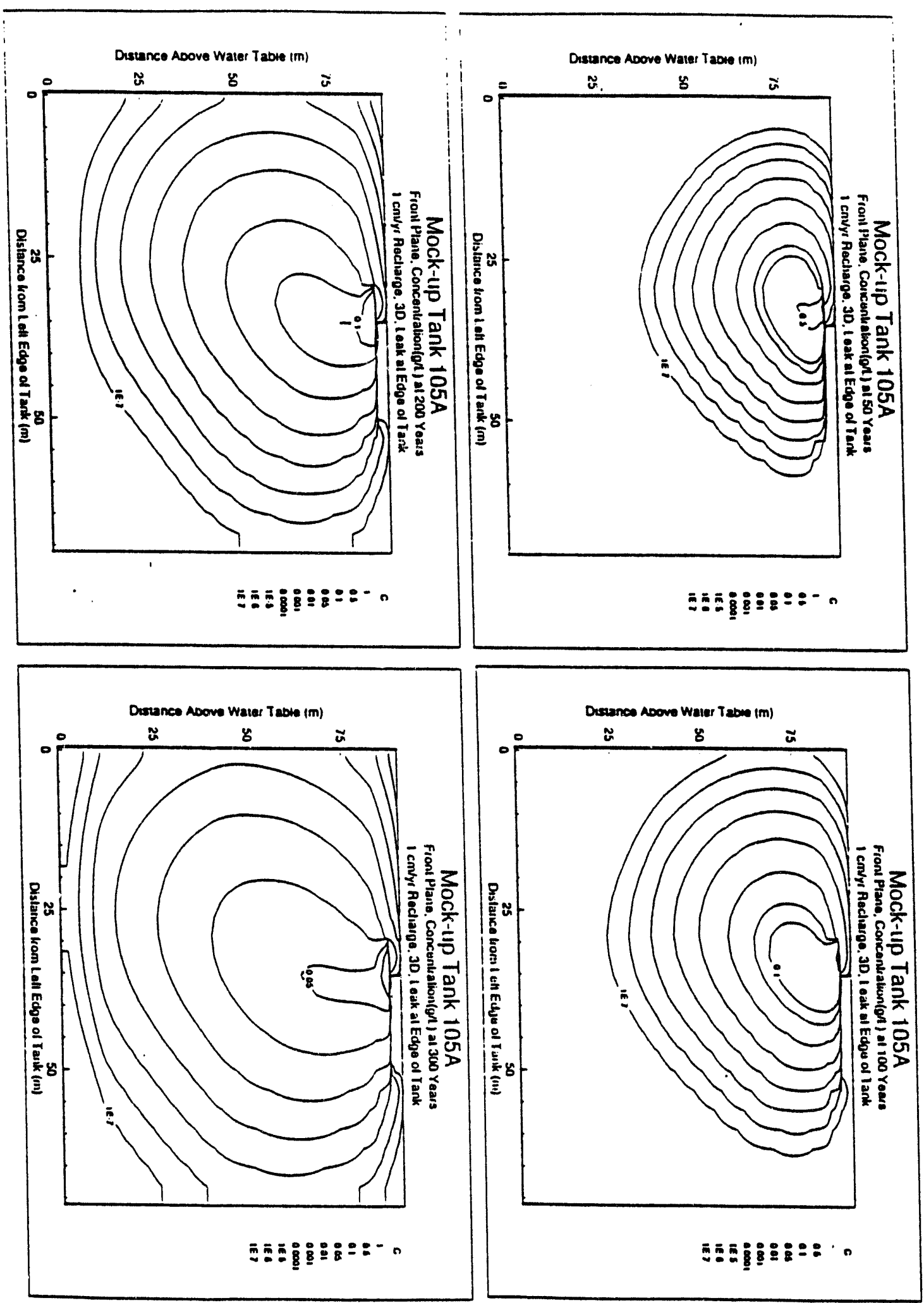

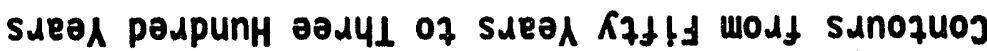

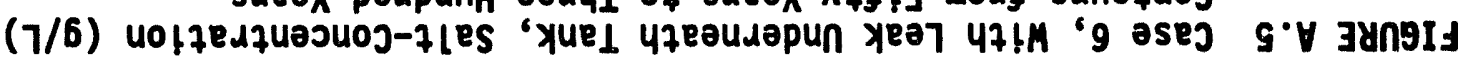



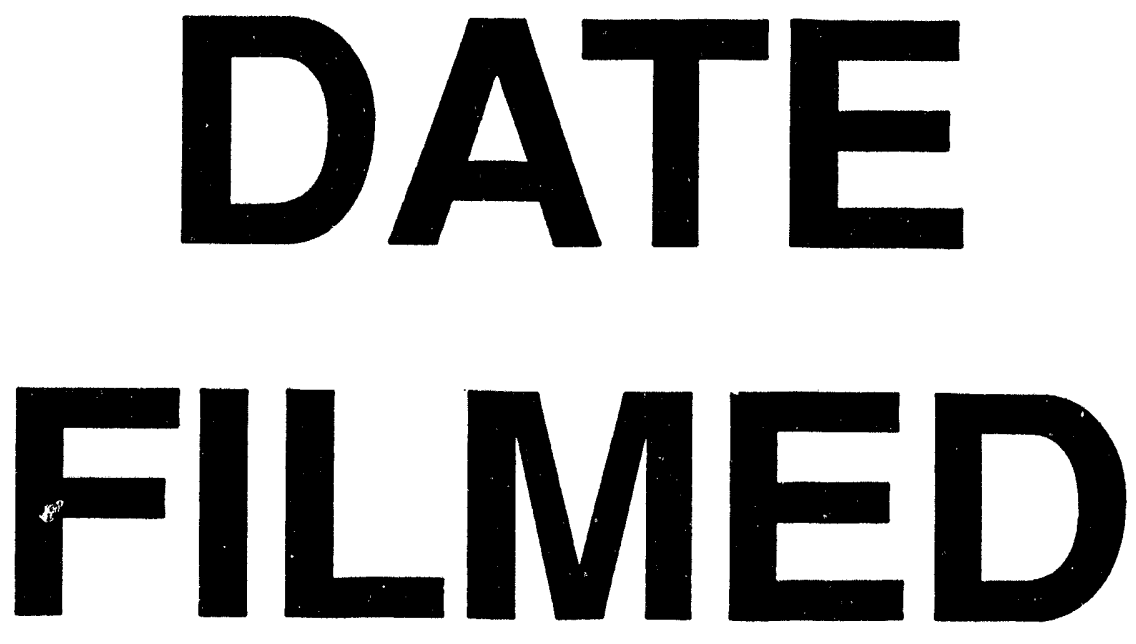

$10 / 24 / 94$
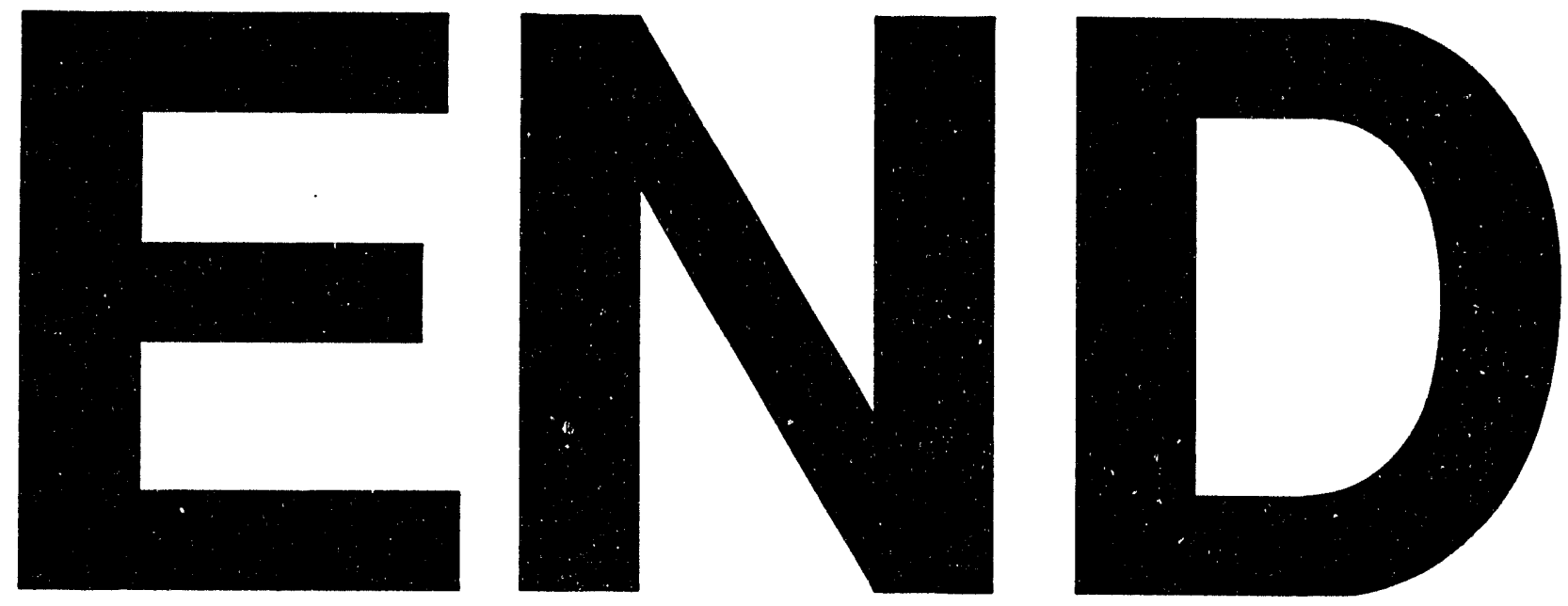
